University of Nebraska - Lincoln

DigitalCommons@University of Nebraska - Lincoln

USGS Staff -- Published Research

US Geological Survey

6-2011

Factors Controlling Pre-Columbian and Early Historic Maize Productivity in the American Southwest, Part 2: The Chaco Halo, Mesa Verde, Pajarito Plateau/ Bandelier, and Zuni Archaeological Regions

Larry Benson

U.S. Geological Survey, great.basin666@gmail.com

Follow this and additional works at: http://digitalcommons.unl.edu/usgsstaffpub

Part of the Agriculture Commons, Agronomy and Crop Sciences Commons, and the Archaeological Anthropology Commons

Benson, Larry, "Factors Controlling Pre-Columbian and Early Historic Maize Productivity in the American Southwest, Part 2: The Chaco Halo, Mesa Verde, Pajarito Plateau/ Bandelier, and Zuni Archaeological Regions" (2011). USGS Staff -- Published Research. 747. http:// digitalcommons.unl.edu/usgsstaffpub/747

This Article is brought to you for free and open access by the US Geological Survey at DigitalCommons@University of Nebraska - Lincoln. It has been accepted for inclusion in USGS Staff -- Published Research by an authorized administrator of DigitalCommons@University of Nebraska - Lincoln. 


\title{
Factors Controlling Pre-Columbian and Early Historic Maize Productivity in the American Southwest, Part 2: The Chaco Halo, Mesa Verde, Pajarito Plateau/ Bandelier, and Zuni Archaeological Regions
}

\author{
Larry V. Benson
}

Published online: 1 June 2010

(C) US Government 2010

\begin{abstract}
Chemical and nutrient analyses of 471 soil samples from 161 sites within four archaeological regions (Pajarito Plateau/Bandelier, Zuni, Mesa Verde, and the Chaco Halo) were combined with historical climate data in order to evaluate the agricultural productivity of each region. In addition, maize productivity and field-life calculations were performed using organic-nitrogen $(\mathrm{N})$ values from the upper $50 \mathrm{~cm}$ of soil in each region and a range $(1-3 \% /$ year) of $\mathrm{N}$-mineralization rates. The endmember values of this range were assumed representative of dry and wet climate states. With respect to precipitation and heat, the Pajarito Plateau area has excellent agricultural potential; the agricultural potentials of the Zuni and Mesa Verde regions are good; and the agricultural potential of the Chaco Halo is poor. Calculations of $\mathrm{N}$ mineralization and field life indicate that Morfield Valley in Mesa Verde should be able to provide $10 \mathrm{bu} / \mathrm{ac}$ of maize for decades (without the addition of $\mathrm{N}$ ) when organic N-mineralization rates exceed $2 \%$. Productivity and field-life potential decrease in the following order: Zuni, Mesa Verde, Bandelier, Chaco Halo. The Chaco Halo is very unproductive; e.g., 10 bushels per acre can be achieved within the Halo only from soils having the highest organic $\mathrm{N}$ concentration (third quartile) and which undergo the highest rate $(3 \%)$ of $\mathrm{N}$ mineralization.
\end{abstract}

Keywords Southwest $\cdot$ Maize agriculture $\cdot$ Soil chemistry $\cdot$ Nitrogen mineralization . Chaco Halo $\cdot$ Mesa Verde $\cdot$ Zuni $\cdot$ Bandelier

Electronic supplementary material The online version of this article (doi:10.1007/s10816-010-9083-y) contains supplementary material, which is available to authorized users.

L. V. Benson $(\bowtie)$

National Research Program, U.S. Geological Survey, 3215 Marine St., Boulder, CO 80303, USA

e-mail: lbenson@usgs.gov 


\section{Introduction}

In Part 1 of this study (Benson 2010), the hydrologic, biological, and chemical processes that mediate the growth of maize in the semi-arid southeastern Colorado Plateau and Rio Grande regions were discussed. In addition, certain measures and methodologies which can be used to evaluate field fertility and field life with respect to the cultivation of maize were introduced. It is the thesis of this study that climate change in the form of extended anomalously wet and dry periods (megadroughts) forced prehistoric cultural response in the American Southwest and that the linkage between climate change and cultural response was mostly due to the dependence of a culture on maize production.

In this paper, the relative agricultural productivity of four specific archaeological regions within the study area, including the Chaco Halo (the region extending from Raton Wells on the east to the base of the Chuska Mountains on the west), Mesa Verde, the Pajarito Plateau/Bandelier, and Zuni are examined in some detail (Fig. 1).

Occupation of each of these regions terminated at different times. The vast majority of those living within the Chaco Halo abandoned this area during the midtwelfth-century megadrought (Judge 1989; Lekson and Cameron 1995). Mesa Verde was abandoned during the late-thirteenth-century megadrought (Varien et al. 1996),

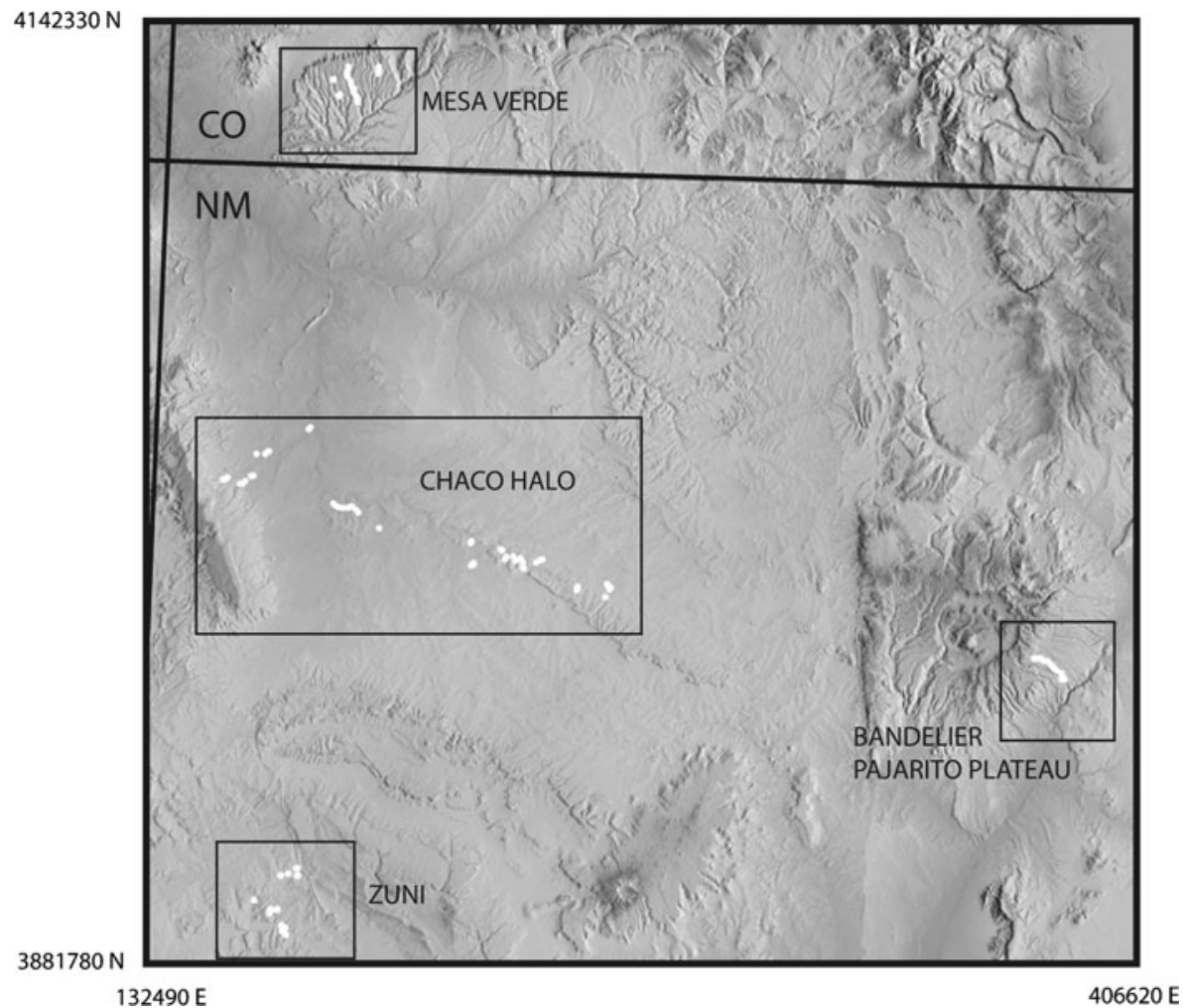

Fig. 1 Study-area location map showing the Mesa Verde, Chaco Halo, Pajarito Plateau, and Zuni archaeological regions. White circles indicate soil sampling locations 
and the Pajarito Plateau was abandoned during the sixteenth century (Orcutt 1991), perhaps in response to the effects of the sixteenth-century megadrought (Stahle et al. 2000). Zuni survived these droughts and remains occupied.

The prehistoric Native Americans that inhabited these four regions may have been culturally linked by a series of migrations that occurred between 800 and 1300 (all dates are C.E.). Wilshusen and Van Dyke (2006) have suggested, using data gleaned from the Chaco Canyon and Navajo Reservoir areas, that people from the Mesa Verde region moved to Chaco Canyon during the late-ninth and tenth centuries. In the early 1100s, some people from Chaco Canyon appear to have moved first to Salmon Pueblo ( 1100) and then to the Aztec Pueblo complex ( 1120) (Windes and Bacha 2008; Brown et al. 2008). After the collapse of the Chacoan world at about 1130, people from the Chaco Halo may have migrated to Zuni (Kintigh et al. 2004) and, during the late 1200s, Mesa Verdeans may have moved to sites in Northern Rio Grande, including the Pajarito Plateau (Ortman 2010; Lipe 2010).

Farming styles differed within the four archaeological regions. Agricultural fields at Zuni (Muenchrath et al. 2002), the Chuska Slope (Friedman et al. 2003), and Chaco Canyon (Vivian 1992) appear to have been recipients of diverted and concentrated warm-season precipitation. Although difficult to identify today, most prehistoric agricultural fields at Mesa Verde were presumably located on the mesa top and received on-field precipitation which was not concentrated. Wycoff (1977), based on a pollen profile from Mummy Lake/Fairview Reservoir-an unroofed Great Kiva in the style of the Ats'ee Nitsaa (Fowler and Stein 1992), suggested that maize cultivation of the Mesa Verde plateau, which included extensive clearing of pinyon-juniper forests, occurred prior to the mesa's abandonment in the latethirteenth century. Check dams also were employed in a staircase manner at Mesa Verde within the upper parts of some side-valley tributaries in order to pond water and soil; however, their total acreage relative to the overall mesa top area is small (Rohn 1963; Stewart 1940).

In the Pajarito Plateau, which contains Bandelier National Monument, the most common agricultural practice was to create fields on gently sloping mesa tops where maize relied directly on precipitation; however, the prehistoric Native Americans in this area also built contour terraces and check dams to concentrate and slow runoff (Gauthier and Herhahn 2005). For an excellent review of the construction characteristics, soil, and hydrologic properties of gridded rock-bordered fields, the reader is referred to the collected works edited by Doolittle and Neely (2004). Although this publication focuses on the Safford Valley site in southeastern Arizona, the insights gathered from this site are applicable to other areas within the southeastern Colorado Plateau and Rio Grande regions. It should be noted that the Safford Valley rock-bordered fields were probably not used for cultivation of maize, but instead may have been used for cultivation of agave.

\section{An Evaluation of Maize Agriculture within the Four Archaeological Regions}

In the following sections, available climate and climate proxy records from meteorological stations within the four archaeological regions (Fig. 1) are examined. Data from the Los Alamos weather station are used to represent the climate of the 
Pajarito Plateau because data from the Bandelier weather station are not available after 1976. Data from the Star Lake weather station, $18 \mathrm{~km}$ east of Pueblo Pintado, are used to represent the climate of the area east of Chaco Canyon. Data from weather stations at Chaco Canyon, Mesa Verde, and Zuni were also used. The fate of warm- and cold-season precipitation is explicated in terms of the processes of evaporation, infiltration, and percolation. Lastly, new soil-chemistry data sets for the four archaeological regions are presented, with soil data from Bandelier National Monument used to represent the soil chemistry of the Pajarito Plateau.

\section{Methods}

Soil samples $(n=471)$ were collected from 161 sites with a hand auger equipped with a 9-cm-diameter stainless steel bucket. When possible, samples were collected from depths of 10-26, 40-46, 70-76, and 100-106 cm. Samples were placed in plastic wide-mouth screw-capped jars and refrigerated until processed. Jars were labeled with site number and sample depth. Locations of samples were obtained using a handheld GPS usually accurate to $<5 \mathrm{~m}$.

Samples were weighed, oven dried, and reweighed prior to calculation of percent moisture. The dried sample was disaggregated using a mortar and pestle and the soil passed through a 2-mm screen; all particles $>2 \mathrm{~mm}$ were discarded. The screened sample was homogenized by cone and quartering. Twenty grams (g) of soil was mixed with $20 \mathrm{~mL}$ of deionized (DI) water in a beaker and let stand for $1 \mathrm{~h}$ with occasional stirring. The sample was then stirred for $30 \mathrm{~s}$ and $\mathrm{pH}$ was measured on the unfiltered mixture, using an IQ Scientific Instruments combination $\mathrm{pH} /$ conductivity instrument. ${ }^{1}$ Ten grams of sample was mixed with $10 \mathrm{~mL}$ of DI water in a beaker and let stand overnight; electrical conductivity (EC) was then measured on the unfiltered sample, using an IQ Scientific Instruments combination $\mathrm{pH} /$ conductivity instrument.

Approximately $4 \mathrm{~g}$ of the homogenized soil was finely ground; $2.5 \mathrm{~g}$ of the ground soil was mixed with $25 \mathrm{~mL}$ of DI water, shaken for $30 \mathrm{~min}$, centrifuged, and the mostly sediment-free water decanted from the centrifuge tube. The soil leachate was then filtered prior to nitrate $\left(\mathrm{NO}_{3}\right)$ analysis using a luer-lock syringe and 0.45 $\mu \mathrm{m}$ filter. Instrumentation used for nitrate analysis included a Dionex DX100 ion chromatograph.

Total carbon $(\mathrm{C})$ and total nitrogen $(\mathrm{N})$ were determined on about $2 \mathrm{mg}$ of ground sample, using an Exeter Analytical Model CE-44O rapid analysis elemental analyzer. Amy Myrbo at the University of Minnesota supervised total inorganic carbon (TIC) analyses of powdered sample that were conducted using a Coulometrics instrument. Available P was determined on powdered soil samples by the Iowa State University Soil and Plant Analysis Laboratory, using the Olsen-P method. Organic $\mathrm{N}$ was determined by subtracting measured $\mathrm{NO}_{3}-\mathrm{N}$ from total $\mathrm{N}$ and total organic $\mathrm{C}$ (TOC) was determined by subtracting measured TIC values from total $\mathrm{C}$.

\footnotetext{
${ }^{1}$ Any use of trade, product, or firm names in this paper is for descriptive purposes only and does not imply endorsement by the U.S. government.
} 
All climate data were obtained from the Western Regional Climate Center either by accessing their web site (http://www.wrcc.dri.edu/) or through the courtesy of James Ashby. Growing degree days (GDD) were calculated for the freeze-free period at each of the archaeological sites.

\section{Climate Records}

\section{Precipitation}

In the following, water year (WY) refers to the 12-month period that ends on September 30th of the water year and starts on October 1st of the previous year. Summer refers to the months of June, July, August, and September and winter refers to the 6-month period beginning October 1st and ending March 31st.

Historical precipitation at Chaco Canyon and Star Lake exceed the minimum amounts of summer (JJAS) and annual (water-year) precipitation necessary for the production of maize (15 and $30 \mathrm{~cm}$, respectively) about one quarter of the time (Table 1, Fig. 2a, b, f, g, k, 1, p, and q). Precipitation at Zuni exceeds the minimum amounts of annual and summer precipitation necessary for the production of maize about half the time (Table 1, Fig. 2c, h, m, and r). Precipitation at Mesa Verde and Los Alamos (Pajarito Plateau) exceeds the minimum annual amount of precipitation necessary for the production of maize most of the time (Table 1, Fig. 2d, e, i, and j); however, Los Alamos receives abundant summer rains whereas Mesa Verde receives summer rains that exceed the minimum value only about half the time (Table 1, Fig. 2n, o, s, and t). In terms of on-field precipitation, the Pajarito Plateau, Mesa Verde, Zuni, and the Chaco Halo are ranked from best to worst.

In terms of seasonal precipitation, Mesa Verde is winter dominated, Los Alamos is summer dominated, whereas Chaco and Zuni receive nearly equal amounts of summer and winter precipitation (Table 2).

Table 1 Water-Year and Summer (JJAS) Precipitation (cm) at Five Sites

\begin{tabular}{|c|c|c|c|c|c|}
\hline & Chaco Canyon & Star Lake & Los Alamos & Mesa Verde & Zuni \\
\hline \multicolumn{6}{|c|}{ Water-year precipitation $(\mathrm{cm})$} \\
\hline Number of years & 65 & 51 & 91 & 76 & 53 \\
\hline 1st quartile & 18.6 & 20.5 & 39.6 & 36.2 & 25.3 \\
\hline 2nd quartile & 21.7 & 24.0 & 46.5 & 45.9 & 32.4 \\
\hline 3rd quartile & 27.5 & 28.5 & 53.5 & 53.5 & 35.0 \\
\hline Mean & 22.4 & 24.0 & 46.8 & 45.0 & 30.2 \\
\hline \multicolumn{6}{|c|}{ Summer (JJAS) precipitation $(\mathrm{cm})$} \\
\hline Number of years & 65 & 54 & 92 & 76 & 56 \\
\hline 1st quartile & 8.0 & 9.1 & 22.2 & 11.9 & 9.7 \\
\hline 2nd quartile & 9.8 & 12.5 & 25.1 & 14.7 & 15.4 \\
\hline 3rd quartile & 13.8 & 15.2 & 28.9 & 18.3 & 18.5 \\
\hline Mean & 10.5 & 12.6 & 25.7 & 15.2 & 14.2 \\
\hline
\end{tabular}



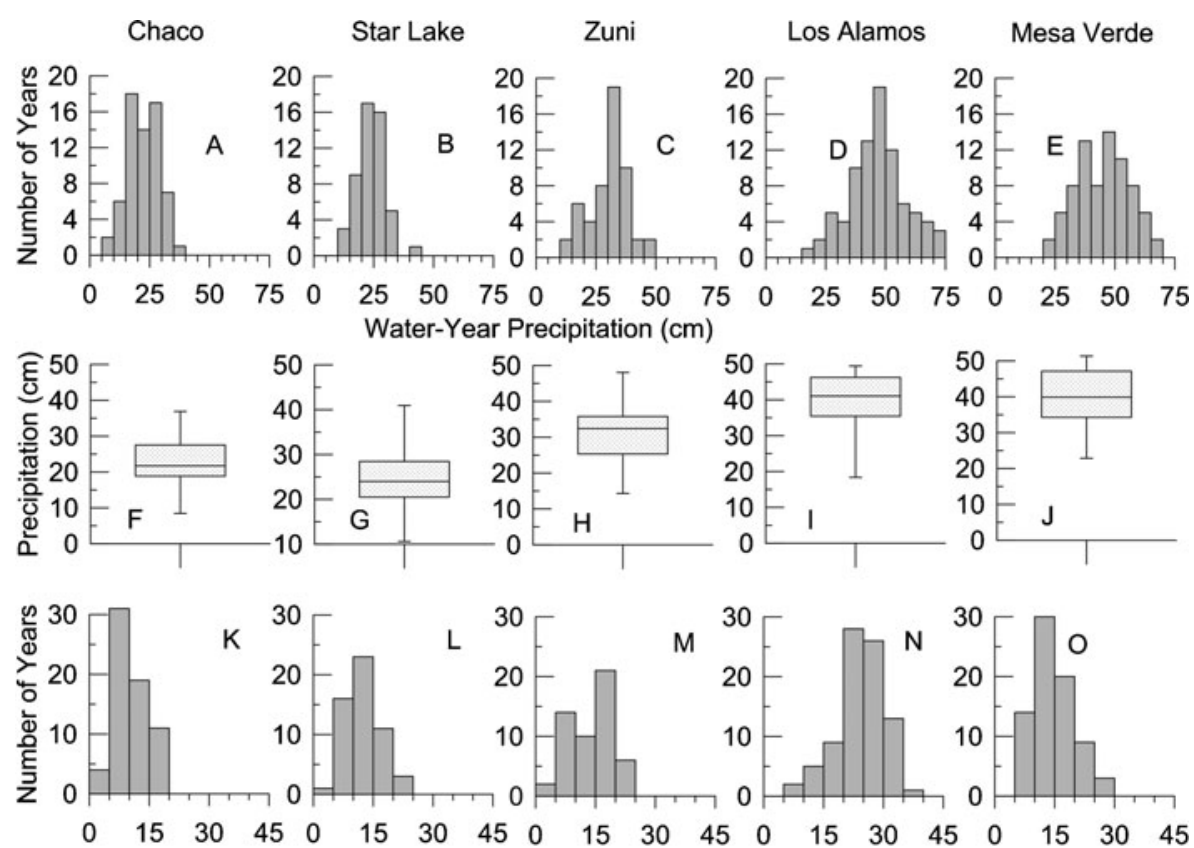

Summer (JJAS) Precipitation (cm)
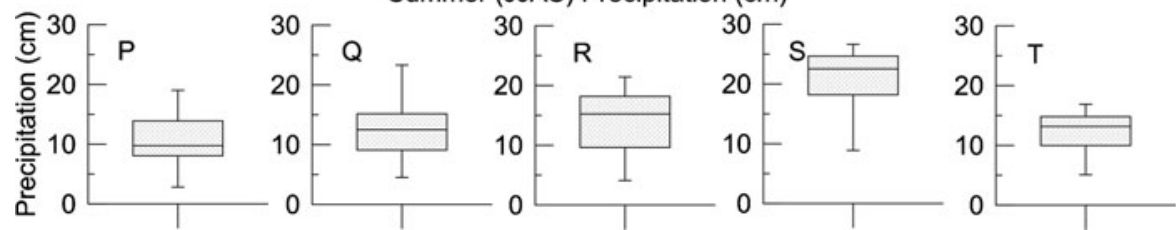

Fig. 2 Water-year and summer (June, July, August, and September) precipitation amounts for weather stations in the four archaeological regions. The Star Lake weather station is located near the eastern end of the Chaco Halo

Summer rains contribute, on average, $10.5,14.2,15.2$, and $25.7 \mathrm{~cm}$ of water, respectively, to Chaco Canyon, Zuni, Mesa Verde, and Los Alamos (Table 2). These summer rains are temporally sporadic, comprising only a few intense convective events; e.g., a precipitation event in which $>0.99 \mathrm{~cm}$ of rain falls within a 24$\mathrm{h}$ period occurs only 0.65 times a month at Chaco Canyon, 1.3 times a month at Zuni, 1.1 times a month at Mesa Verde, and 2.1 times a month at Los Alamos. A storm producing $>1.99 \mathrm{~cm}$ of precipitation occurs only $0.4,1.4,1.5$, and 1.9 times during each 120-day growing season at, respectively, Chaco, Zuni, Mesa Verde, and Los Alamos (Table 3).

\section{Infiltration, Percolation, Bare-Soil Evaporation, and the Fate of Summer Precipitation}

In summer, about $10 \mathrm{~mm}$ of water can be rapidly evaporated from the surface layer of a silt loam after the layer has been completely wetted (Allen et al. 2005 and references therein). Early historic maize plant densities imply that only $\sim 11 \%$ of the soil surface will be shaded by maize at noon (Benson 2010); thus, bare-soil evaporation will be relatively high under these conditions. Given that semi-arid 
Table 2 Precipitation at Mesa Verde, Zuni, Chaco Canyon, and Los Alamos

\begin{tabular}{|c|c|c|c|c|}
\hline Site & Mesa Verde & Zuni & Chaco Canyon & Los Alamos \\
\hline Period of record & 1924-2008 & 1949-2008 & 1933-2008 & 1911-2008 \\
\hline Complete years of record & 76 & 53 & 65 & 91 \\
\hline \multicolumn{5}{|l|}{ Summer precipitation statistics } \\
\hline$X_{\text {SUM }} \mathrm{P}(\mathrm{cm})$ & 15.2 & 14.2 & 10.5 & 25.7 \\
\hline$\sigma_{\text {SUM }} \mathrm{P}(\mathrm{cm})$ & 5.1 & 5.6 & 3.8 & 7.2 \\
\hline \multicolumn{5}{|l|}{ Water year vs. summer precipitation } \\
\hline$X_{\mathrm{WY}} \mathrm{P}(\mathrm{cm})$ & 45.0 & 30.2 & 22.4 & 46.8 \\
\hline$\sigma_{\mathrm{WY}} \mathrm{P}(\mathrm{cm})$ & 10.6 & 7.9 & 6.4 & 11.7 \\
\hline Dry $_{W Y}$ (no.) & 14 & 11 & 9 & 13 \\
\hline $\operatorname{Dry}_{W Y}(\%)$ & 18 & 21 & 14 & 16 \\
\hline $\mathrm{P}_{\mathrm{SU}}<\mathrm{P}_{X, \mathrm{SUM}}(\%) \mathrm{DRY}_{\mathrm{WY}}$ & 79 & 91 & 100 & 92 \\
\hline $\mathrm{P}_{\mathrm{SUM}}<\mathrm{P}_{X-\sigma, \mathrm{SUM}}(\%) \mathrm{DRY}_{\mathrm{WY}}$ & 43 & 45 & 67 & 62 \\
\hline Wet $_{\mathrm{WY}}$ (no.) & 12 & 8 & 10 & 13 \\
\hline Wet $_{\mathrm{Wy}}(\%)$ & 16 & 15 & 15 & 16 \\
\hline $\mathrm{P}_{\mathrm{SUM}}>\mathrm{P}_{X, \mathrm{SUM}}(\%) \mathrm{WET}_{\mathrm{WY}}$ & 58 & 100 & 90 & 77 \\
\hline $\mathrm{P}_{\mathrm{SUM}}>\mathrm{P}_{X-\sigma, \mathrm{SUM}}(\%) \mathrm{WET}_{\mathrm{WY}}$ & 33 & 50 & 60 & 39 \\
\hline \multicolumn{5}{|l|}{ Winter vs. summer precipitation } \\
\hline$X_{\mathrm{WIN}} \mathrm{P}(\mathrm{cm})$ & 24.0 & 13.2 & 9.1 & 15.3 \\
\hline$\sigma_{\mathrm{WIN}}(\mathrm{cm})$ & 8.2 & 5.0 & 3.8 & 7.1 \\
\hline Dry wIN $_{\text {(no.) }}$ & 13 & 8 & 12 & 14 \\
\hline Dry $_{\text {WIN }}(\%)$ & 17 & 15 & 18 & 16 \\
\hline $\mathrm{P}_{\text {SUM }}<\mathrm{P}_{X, \text { SUM }}(\%) \mathrm{DRY}_{\text {WIN }}$ & 31 & 62 & 50 & 57 \\
\hline $\mathrm{P}_{\mathrm{SUM}}<\mathrm{P}_{X-\sigma, \mathrm{SUM}}(\%) \mathrm{DRY}_{\mathrm{WIN}}$ & 15 & 25 & 25 & 21 \\
\hline Wet $_{\text {WIN }}$ (no.) & 15 & 11 & 9 & 16 \\
\hline Wet $_{\text {WIN }}(\%)$ & 20 & 21 & 14 & 19 \\
\hline $\mathrm{P}_{\text {SUM }}>\mathrm{P}_{X, \mathrm{SUM}}(\%) \mathrm{WET}_{\mathrm{WIN}}$ & 27 & 31 & 56 & 47 \\
\hline PSUM $>\mathrm{P}_{X-\sigma, \mathrm{SUM}}(\%) \mathrm{WET}_{\mathrm{WIN}}$ & 13 & 9 & 11 & 7 \\
\hline \multicolumn{5}{|l|}{ Wet winters vs. dry summers } \\
\hline $\mathrm{P}_{\mathrm{SUM}}<\mathrm{P}_{X, \mathrm{SUM}}(\%) \mathrm{WET}_{\mathrm{WIN}}$ & 73 & 55 & 44 & 60 \\
\hline $\mathrm{P}_{\mathrm{SUM}}<\mathrm{P}_{X-\sigma, \text { SUM }}(\%) \mathrm{WET}_{\mathrm{WIN}}$ & 20 & 36 & 11 & 20 \\
\hline
\end{tabular}

$X$ (average), $\sigma$ (standard deviation), $P$ (precipitation), WY (water year), SUM (summer (JJAS)), WIN (winter (ONDJFM)), $P_{S U M}<P_{X, S U M}(\%) D R Y_{W Y}$ (summers with $\mathrm{P}$ less than average during dry WY), $P_{S U M}<P_{X-\sigma, S U M}(\%) D R Y_{W Y}$ (summers with P more than $1 \sigma$ below average during dry WY), $P_{S U M}>P_{X}$, $S U M(\%) W E T_{W Y}$ (summers with $\mathrm{P}$ greater than average during wet WY), $P_{S U M}>P_{X-\sigma, S U M}(\%) W E T_{W Y}$ (summers with $\mathrm{P}$ more than $1 \sigma$ above average during wet WY)

regions such as the American Southwest experience free-surface evaporation rates ranging from 5 to $8 \mathrm{~mm} /$ day (Abdul-Jabbar et al. 1983; figure 2 in Benson and White 1994), it follows that water will be removed from the saturated soil-surface layer within a few days during the growing season.

Cumulative evaporation from a silt-loam soil subjected to potential free-surface rates of evaporation ranging from 6.3 to $15 \mathrm{~mm} /$ day is shown in Fig. 3 (Jalota and 


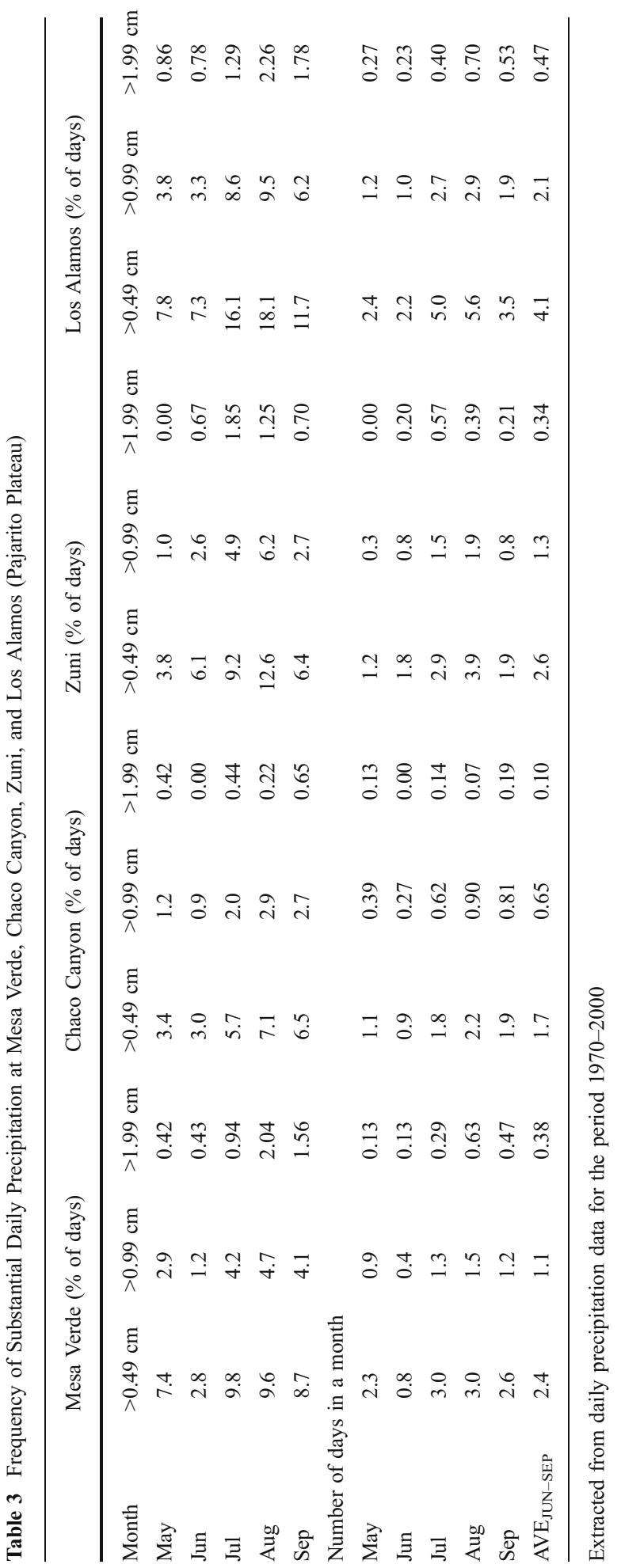




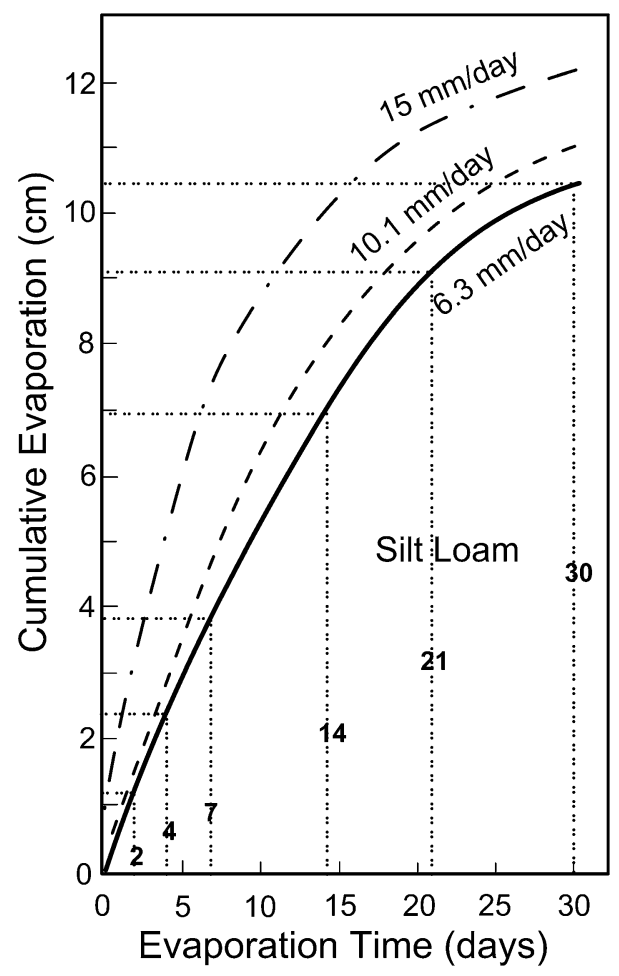

Fig. 3 Cumulative evaporation from a silt-loam soil as a function of three bare-soil evaporation rates (data from Jalota and Prihar 1986)

Prihar 1986). An evaporation rate typical of the Southwest during the warm season (6.3 mm/day) applied to silt loam removes approximately 0.6, 1.2, 2.4, 3.8, 7.0, 9.1, and $10.5 \mathrm{~cm}$ of shallow infiltrating precipitation within about 1, 2, 4, 7, 14, 21, and 30 days (Figs. 3 and 4 ). Note that increases in soil permeability (loam sand $>$ sandy loam $>$ silt loam) result in decreased cumulative evaporation (Fig. 4) because percolating soil water moves deeper in the soil zone with increasing soil permeability, slowing water-vapor transport to the surface.

Given that bare-soil evaporation will remove about $1 \mathrm{~cm}$ of readily available soil water in 2 days, how much of the infiltrating precipitation will the maize be able to acquire (transpire) in the same time period? Maize dry-matter (DM) accumulation obeys an equation called the Richards function (Richards 1959); i.e.,

$$
M_{\text {dry }}=A\left(1 \pm e^{(b-k t)}\right)^{-1 / n}
$$

where $M_{\mathrm{dry}}$ is the mass of the dry plant, $A$ is the asymptotic maximum size of the plant (a constant), $t$ is time, and $b, K$, and $n$ are constants.

Berzsenyi and Lap (2004) have fit the Richard's function to data for the production of maize DM and have shown that the absolute growth rate of maize (planted at a density of 8,100 plants/ac) accelerates from 1 to $8 \mathrm{~g} \mathrm{DM} /$ plant/day between 40 and 75 days after sowing and then slows to $2 \mathrm{~g} \mathrm{DM} /$ plant/day at day 140; i.e., the absolute growth rate is characterized by a bell-shaped curve. 


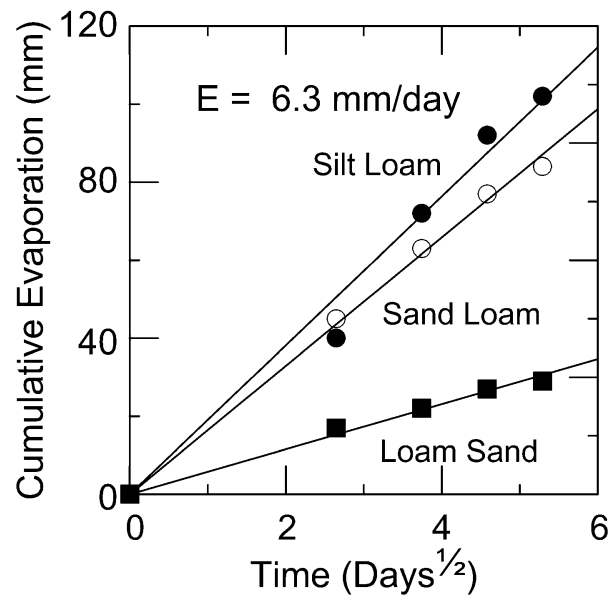

Fig. 4 Cumulative evaporation in different soil types subjected to a bare-soil evaporation rate of $6.3 \mathrm{~mm} /$ day (data from Jalota and Prihar 1986)

Maize DM is composed of 43.6\% C (Latshaw and Miller 1924), and for every gram of $\mathrm{C}$ fixed about $375 \mathrm{~g}$ of $\mathrm{H}_{2} \mathrm{O}$ is transpired (Taiz and Zeiger 2002:62). At their maximum extent, which we assume occurs 75 days after sowing, the roots of maize can extend $1.2 \mathrm{~m}$ laterally from the stalk (Weaver 1926). Thus, at 75 days, the roots cover a ground surface area of $4.5 \mathrm{~m}^{2}$ and the plant transpires a maximum of $1,305 \mathrm{~g}$ of $\mathrm{H}_{2} \mathrm{O}$ each day. Therefore, during the 2 days it would take a silt loam to lose $1 \mathrm{~cm}$ of water to the atmosphere (Fig. 3), the plant will transpire $2,610 \mathrm{~cm}^{3}$ of $\mathrm{H}_{2} \mathrm{O}$, which is only $5.8 \%$ of the $45,000 \mathrm{~cm}^{3}$ of water intercepted by the $4.5-\mathrm{m}^{2}$ root area during a $1-\mathrm{cm}$ precipitation event. If precipitation occurs earlier in the growth history of the crop, e.g., at day 40 when the plant grows at a rate of $1 \mathrm{~g} \mathrm{DM} /$ day, evaporation of a $1-\mathrm{cm}$ precipitation event will allow only $326 \mathrm{~cm}^{3}$ of $\mathrm{H}_{2} \mathrm{O}$ to be transpired, which is only $1.2 \%$ of the intercepted water.

These calculations indicate that the relatively intense summer rains that fell between 1970 and 2000 (Table 3) did not, on average, provide sufficient water to support the efficient production of maize within the four archaeological regions discussed in this paper.

\section{Evaporation/Sublimation, Infiltration, and the Fate of Winter Precipitation}

Winter precipitation is of paramount importance in initializing the growth of maize; Chaco Canyon, Zuni, Los Alamos, and Mesa Verde receive, on average, 34.5, 42.7, 97.2, and $190 \mathrm{~cm}$ of snow between September 30 and April (Western Regional Climate Center 2009). These snow amounts correspond, approximately and respectively, to 3.5, 4.3, 9.7, and $19 \mathrm{~cm}$ of precipitable water (Singh and Singh 2001:121).

Melting snow has a much greater chance of infiltrating the soil zone during the winter given that bare-soil evaporation and plant transpiration are much reduced during the cold season. Snowmelt should not have difficulty penetrating soils at the four sites; only Mesa Verde and Zuni experience mean daily temperatures below $0^{\circ} \mathrm{C}$ in the winter with those below-freezing days falling between December 15 and 
January 15 . Maximum daily temperatures during the same time period exceed $4.5^{\circ} \mathrm{C}$ at these sites; therefore, frozen ground should not present a barrier to infiltrating snowmelt.

Evaporation (including sublimation) of snow is somewhat difficult to estimate. West (1962) measured snow-evaporation rates of $0.17,0.28$, and $0.19 \mathrm{~mm} \mathrm{H}_{2} \mathrm{O} /$ day in a central Sierra Nevada open forest for the period January through May in, respectively, 1958, 1959, and 1960. Barry (1992:169) documented rates of snow evaporation at the Sonnblick Observatory, Austria, that averaged $0.22 \mathrm{~mm} /$ day from November 1 through March 31, 1969-1976. We, therefore, adopt an average snowevaporation rate of $0.2 \mathrm{~mm} /$ day for the study area.

In an average year, Chaco Canyon, Zuni, Mesa Verde, and Los Alamos have snow on the ground for, respectively, 105, 150, 190, and 165 days (Western Regional Climate Center, 2009). Therefore, potential evaporation loss at each of the sites is, respectively, $2.1,3.0,3.8$, and $3.3 \mathrm{~cm}$. These calculations indicate that only 1.4 and $1.3 \mathrm{~cm}$ of water will infiltrate Chaco Canyon and Zuni soils whereas 5.9 and $15.7 \mathrm{~cm}$ of water will infiltrate Los Alamos (Pajarito Plateau) and Mesa Verde soils. This calculation, however, underestimates the total amount of water infiltrating soils at the four sites. Precipitable water in snow makes up 38\%, 32\%, $80 \%$, and $77 \%$ of the total amount of precipitation received, respectively, by Chaco Canyon, Zuni, Los Alamos, and Mesa Verde soils during the winter months (Western Regional Climate Center 2009); therefore, the four regions receive, on average, 5.8, 9.0, 3.0, and $5.6 \mathrm{~cm}$ of rain during the winter, most of which probably infiltrates the soil; i.e., bare-soil evaporation during the winter (October 1-March 31) will be limited in the four regions because their surfaces, for much of the time, are snow covered.

Snow cover reduces bare-soil evaporation because evaporation takes place at the snow-air surface, not at the snow-soil surface. For example, Mesa Verde is snow covered 165 out of 182 winter days. If none of the infiltrating snow melt and rain is lost to "bare-soil" evaporation, a total of $7.2,10.3,8.9$, and $21.3 \mathrm{~cm}$ of water will infiltrate, respectively, Chaco Canyon, Zuni, Los Alamos, and Mesa Verde soils during the winter.

Many of the soils at each of the sites are silt loams which have porosities of about 0.56 and field capacities of about 0.30 (Norton and Silvertooth 1998). Loams and sand loams are also present at Zuni (Homburg et al. 2005). Porosity is the total fraction of pores in a volume of soil and the field capacity is the total fraction of pores in a volume of soil that are water filled after percolation through the soil has ceased. Thus, in a silt-loam soil, winter precipitation can penetrate to depths of approximately 24, 34, 30, and $71 \mathrm{~cm}$ in soils at Chaco Canyon, Zuni, Los Alamos, and Mesa Verde.

As discussed in a previous section of this paper, water penetrating only a few centimeters will be strongly subject to bare-soil evaporation in the summer; therefore, restriction of winter moisture may be an important factor with regard to plant growth at Chaco Canyon, Zuni, and Los Alamos. However, the deep penetration of winter moisture at Mesa Verde may reserve much of the winterderived water for plant transpiration during the following spring and summer.

\section{Is There a Relationship Between Winter and Summer Moisture?}

Dendroclimatologists have yet to develop an accurate method for extracting summer moisture from tree-ring characteristics, although Meko and Baisan (2001) have had 
some success in using Douglas fir late-wood widths to predict dry summers. This indicates that the prehistoric winter-moisture record revealed in tree rings cannot yet be linked to a measure of summer moisture recorded in tree rings; therefore, we must turn to historical climate records to determine if summer moisture is related to winter moisture within a particular archaeological region.

In the following, the words wet and dry are used, respectively, to indicate seasons or years in which precipitation exceeds or falls short of the average value by $1 \sigma$. Dry water years occur between $14 \%$ and $21 \%$ and wet water years occur between $15 \%$ and $16 \%$ of the time in the four archaeological regions (Table 2). Because summer rains make up $50 \%$ or more of the total annual precipitation received by Zuni, Los Alamos, and Chaco Canyon, a dry water year is associated with a drier-than-average summer $91-100 \%$ of the time and a wet water year is associated with a wetter-than-average summer $77-100 \%$ of the time; i.e., the increase or decrease in summer moisture "levers" the annual value.

At Zuni, Los Alamos, and Chaco Canyon, dry water years are accompanied by summers in which precipitation falls more than $1 \sigma$ below the mean between $45 \%$ and $67 \%$ of the time (Table 2 ). In the three regions, wet water years are accompanied by summers in which precipitation exceeds the mean by $1 \sigma$ between $39 \%$ and $60 \%$ of the time. Mesa Verde receives only $25 \%$ of its water-year precipitation during summer; therefore, dry/wet summers are not as well correlated with dry/wet water years at Mesa Verde.

In order to determine if summer precipitation is linked to winter precipitation, winter precipitation was compared with precipitation received during the following summer (Table 2). During dry winters, summers with below-average precipitation occurred, respectively, $62 \%, 50 \%$, and $57 \%$ of the time at Zuni, Chaco, and Los Alamos; wet winters were associated with above-average summer precipitation $31 \%, 56 \%$, and $47 \%$ of the time and with below-average summer precipitation $55 \%, 44 \%$, and $60 \%$ of the time (Table 2). Given that there is a $50 \%$ chance that summer precipitation would be either above or below average in a given year, it appears that summer precipitation at the four sites is not strongly linked, either in a positive or a negative sense, to the previous winter's precipitation.

The historical precipitation data indicate a tendency for below-average summer precipitation to follow wet winters at Mesa Verde. In general, the historic precipitation data sets do not indicate a strong linkage between the amounts of winter and summer precipitation; therefore, the winter-related treering widths discussed in this paper are not useful in estimating past summer precipitation.

\section{The Seasonal Distribution of Precipitation and Its Effect on N Mineralization}

As discussed in Part 1 of this study (Benson 2010), the principal environmental factors controlling $\mathrm{N}$ mineralization are soil moisture and temperature; i.e., organic $\mathrm{N}$ is slowly converted to $\mathrm{NH}_{4}{ }^{+}$and $\mathrm{NO}_{3}-\mathrm{N}$ by bacterial action during the warm season when greater soil moisture translates into enhanced rates of microbial activity. In Fig. 5, monthly precipitation data (1971-2000) from Chaco Canyon, Zuni, Los Alamos, and Mesa Verde are contrasted with precipitation data from two 

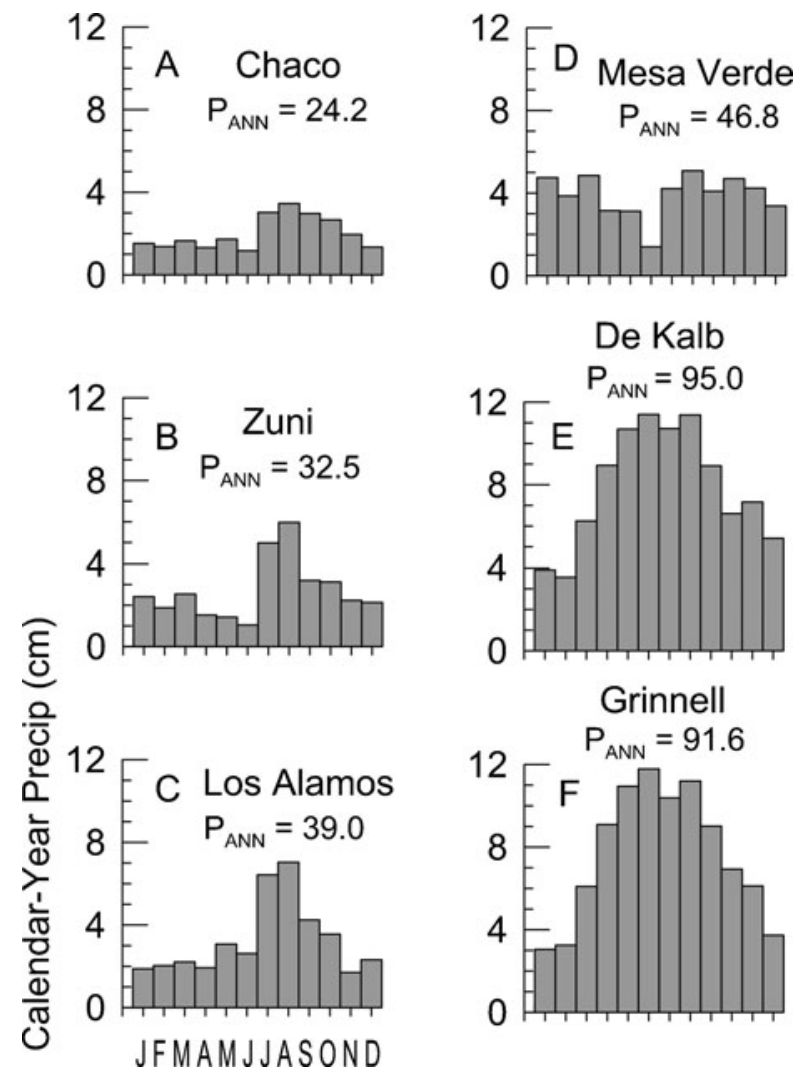

Fig. 5 Mean-monthly precipitation distributions at weather stations in four archaeological regions within the study area (a-d) and two Midwestern Corn Belt sites (e-f)

Midwestern Corn Belt sites-De Kalb, Illinois, and Grinnell, Iowa (USA Climate Archive 2009). The records indicate that the Midwest receives much greater precipitation amounts, especially in the months April through September.

The Southwest is relatively dry in the spring (Fig. 5, Table 4); therefore, the timing and amount of precipitation in this region is not particularly conducive to the mineralization of soil organic matter and the production of $\mathrm{NO}_{3}-\mathrm{N}$ during the early growth stages of maize in spring and early summer. This implies that the carryover of stored winter soil moisture through the early part of the growing season is an essential factor in the production of maize in the semi-arid Southwest.

\section{Growing Degree Days and Freeze-Free Days}

Most varieties of maize, including Southwest Native American landraces such as Hopi blue maize and a variety of Zuni cultivars, require about 120 freeze-free days (FFD) (Bradfield 1971; Muenchrath et al. 2002). In a recent experimental maize grow out in the Durango District of southwestern Colorado, Bellorado (2007) showed that five southwestern Native American maize varieties reached maturity 


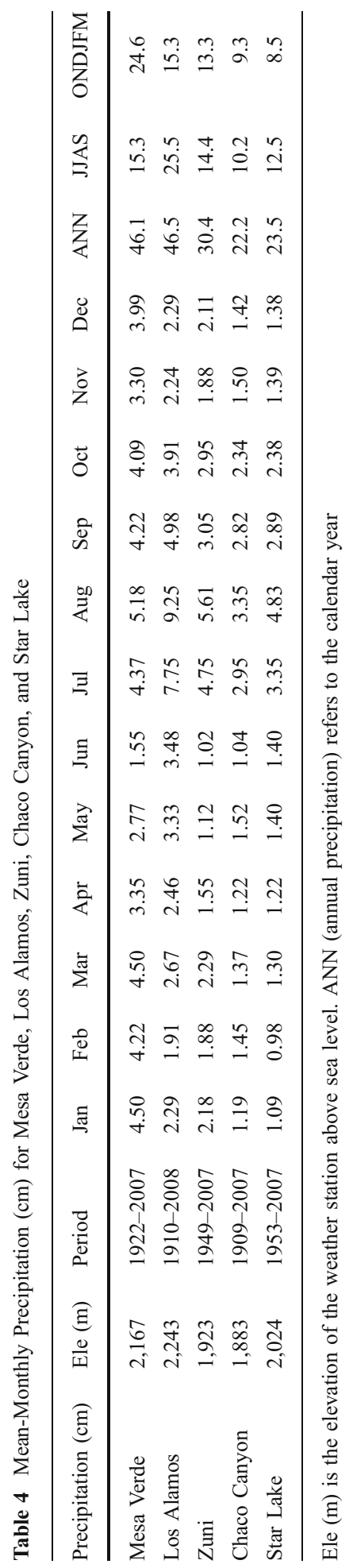


Table 5 Growing Degree Days (GDD) and Freeze-Free Days (FFD) for Five Study Area Weather Stations

\begin{tabular}{|c|c|c|c|c|c|c|c|c|c|c|}
\hline \multirow{2}{*}{$\frac{\text { Site }}{\text { Elevation (m) }}$} & \multicolumn{2}{|c|}{ Chaco Canyon } & \multicolumn{2}{|c|}{ Star Lake } & \multicolumn{2}{|c|}{ Los Alamos } & \multicolumn{2}{|c|}{ Mesa Verde } & \multicolumn{2}{|l|}{ Zuni } \\
\hline & 1,886 & & 2,024 & & 2,243 & & 2,124 & & 1,966 & \\
\hline \multirow[t]{2}{*}{ Time period: } & \multicolumn{2}{|c|}{1948 thru 2008} & \multicolumn{2}{|c|}{1953 thru 2007} & \multicolumn{2}{|c|}{1948 thru 2008} & \multicolumn{2}{|c|}{1948 thru 2008} & \multicolumn{2}{|c|}{1949 thru 2008} \\
\hline & GDD & FFD & GDD & FFD & GDD & FFD & GDD & FFD & GDD & FFD \\
\hline 1st quartile & 1,070 & 100 & 936 & 103 & 1,106 & 144 & 1,192 & 138 & 1,176 & 125 \\
\hline 2nd quartile & 1,198 & 116 & 1,050 & 114 & 1,196 & 156 & 1,366 & 148 & 1,302 & 139 \\
\hline 3rd quartile & 1,302 & 133 & 1,170 & 125 & 1,293 & 170 & 1,454 & 162 & 1,430 & 153 \\
\hline Mean & 1,183 & 119 & 1,055 & 114 & 1,199 & 156 & 1,327 & 149 & 1,291 & 138 \\
\hline
\end{tabular}

within 1,055 to 1,110 GDD. This suggests that at least 1,000 GDD are needed for maize production.

FFD and GDD statistics from weather stations in the four archaeological regions are listed in Table 5 and displayed in Fig. 6. The great majority of the growing
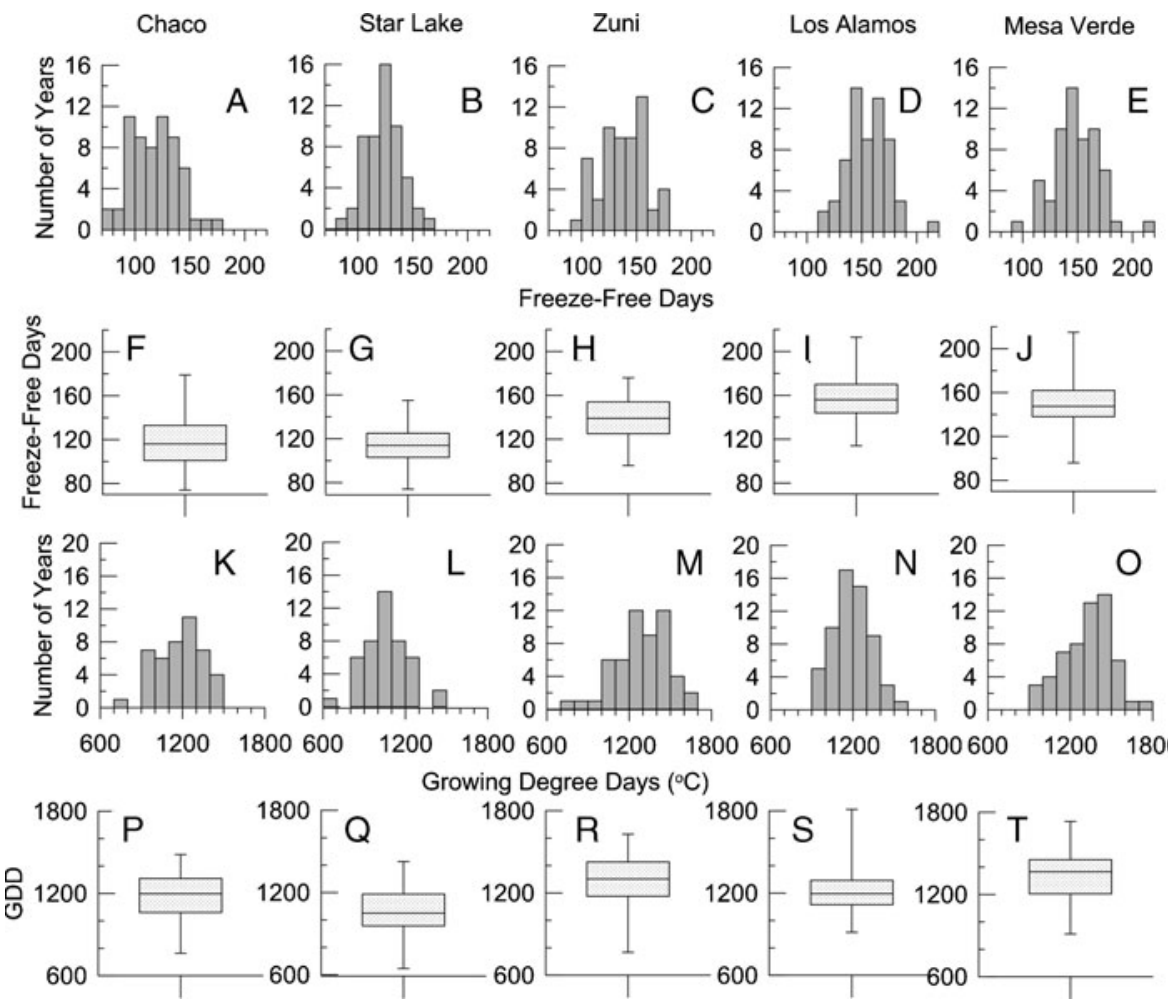

Growing Degree Days $\left({ }^{\circ} \mathrm{C}\right)$
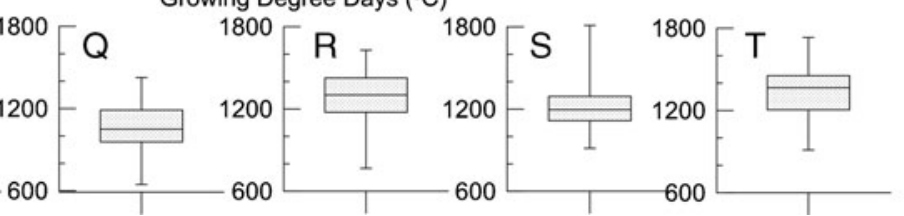

Fig. 6 Histograms and box-whisker plots of freeze-free and growing degree days from five weather stations located within the four archaeological regions. In this and similar figures which follow, the caps at the end of each box indicate the extreme values (minimum and maximum), the box is defined by the lower and upper quartiles $(\mathrm{Q})$, and the line in the center of the box is the median. Outliers, shown as filled circles, are defined as the 1 st $\mathrm{Q}-1.5 \times(3 \mathrm{rd} \mathrm{Q}-1 \mathrm{st} \mathrm{Q})$ and the 3 rd $\mathrm{Q}+1.5 \times(3 \mathrm{rd} \mathrm{Q}-1 \mathrm{st} \mathrm{Q})$ 


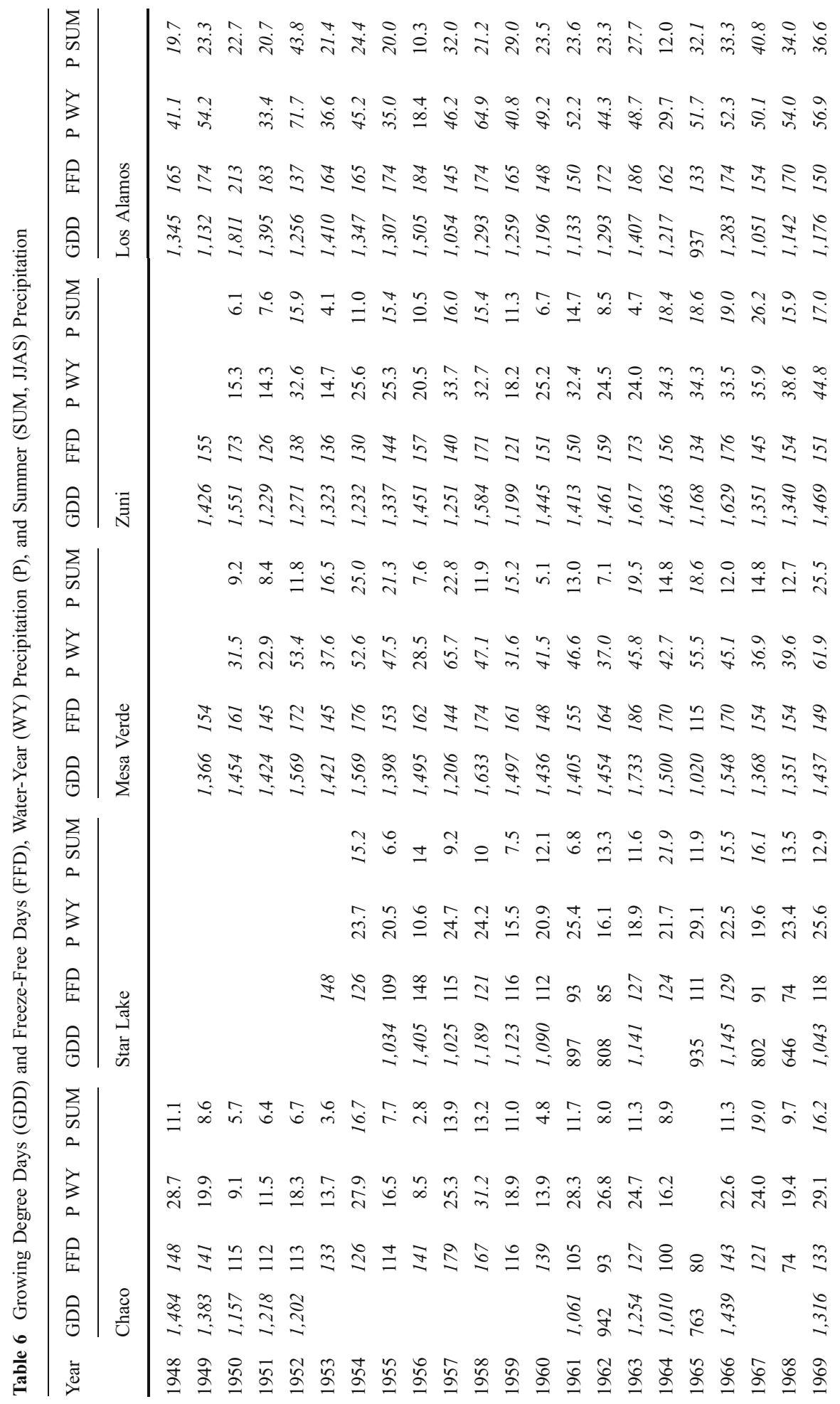




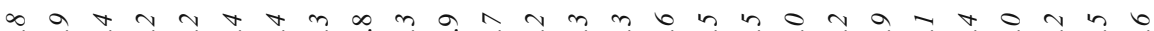

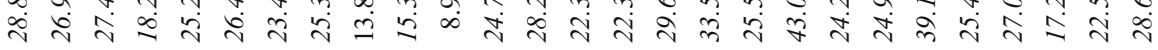

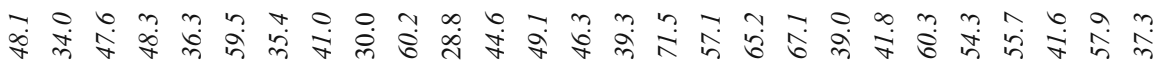

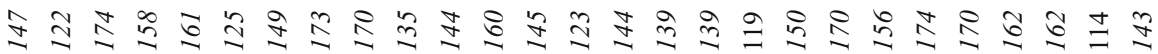

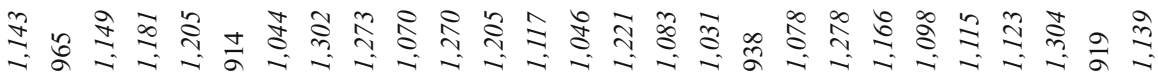
iิ $\stackrel{2}{2}$

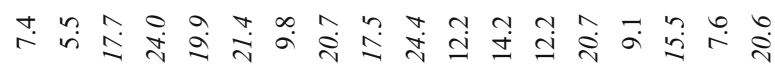

$\vec{m} \stackrel{n}{m} \leftrightarrows$

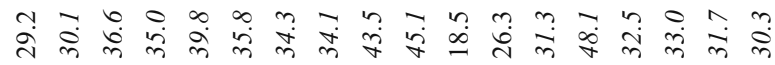

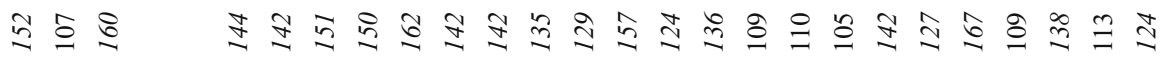

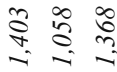

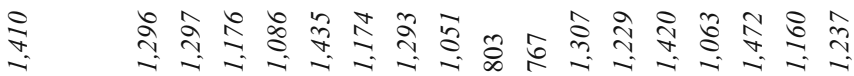
ঐे

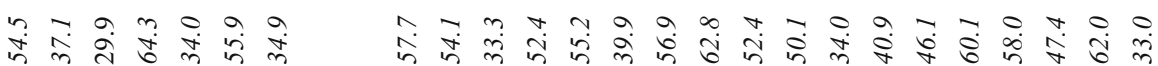

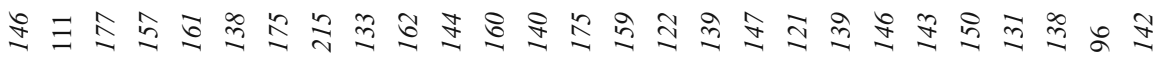

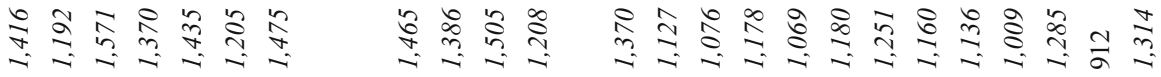

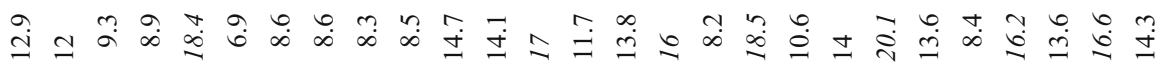

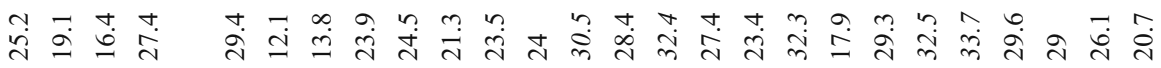

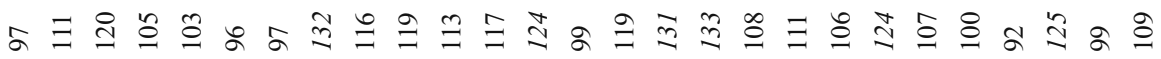

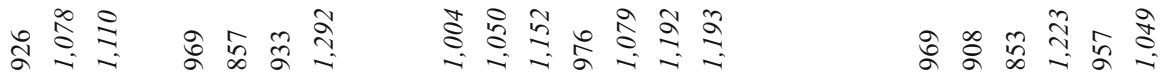

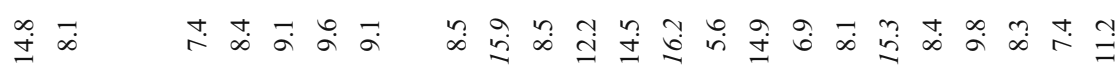

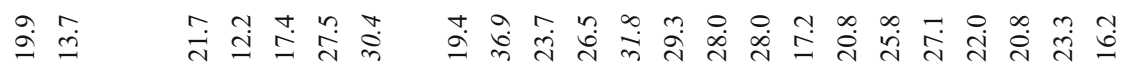
ลิ

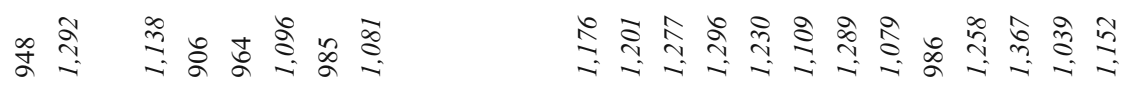

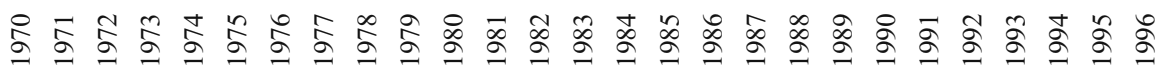




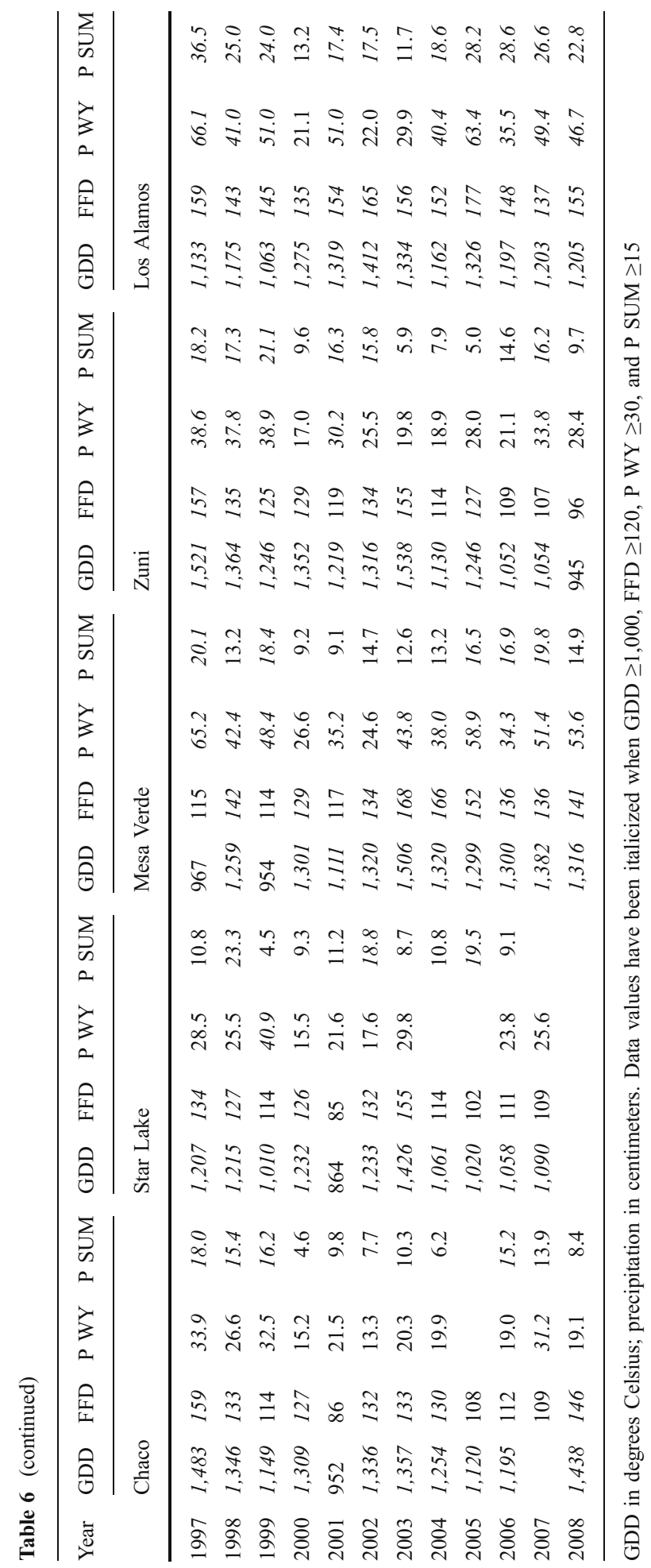


seasons at Zuni, Los Alamos, and Mesa Verde exceed 120 FFD; however, nearly half the growing seasons at Chaco and Star Lake do not meet this criterion. Most of the growing seasons at Zuni, Los Alamos, and Mesa Verde exceed 1,000 GDD; however, approximately one third of the growing seasons at Chaco and Star Lake in the Chaco Halo do not meet this criterion.

Interestingly enough, Petersen (1987) found a negative relationship between GDD at Yellow Jacket, Colorado, and the productivity of unirrigated dryland maize grown in Dolores and Montezuma Counties, Colorado, between 1920 and 1960. It was previously noted that increased solar radiation permits more photosynthetic activity; however, increased solar radiation also increases transpiration and bare-soil evaporation. For situations in the semi-arid Southwest, where soil moisture may limit maize productivity, increased solar radiation actually may negatively impact soil moisture to the extent that it limits transpiration, causing the plant to wilt.

In Table 6 are listed annual GDD, FFD, water-year, and summer precipitation data for Chaco, Star Lake, Mesa Verde, Zuni, and Los Alamos for the period 1948 to 2008. When a climate-parameter value exceeds the minimum value required for the cultivation of maize, it has been italicized. These data sets indicate that maize can be reliably grown at Los Alamos almost every year, that winter or summer precipitation is deficient at Zuni about $50 \%$ of the time, that summer precipitation limits Mesa Verde maize production about $60 \%$ of the time, and that at Chaco and Star Lake all four climate criteria have been met only a few times in the past six decades. It should be noted that if the FFD criterion is lowered from 120 to 105 days, it becomes consistent with the 1,000 GDD criterion.

\section{Proxy-Climate Records of Prehistoric Precipitation}

\section{Tree-Ring Widths and Their Relation to the Seasonality of Precipitation}

Calibrations of precipitation to standardized tree-ring widths are often made with different 12-month periods. In the southern Colorado Plateau, one of the most common annual-precipitation calibrations invokes the period starting with the previous August and ending with the current July (e.g., Rose et al. 1981); however, some researchers prefer a 12-month period starting with the previous July and ending with the current July (e.g., Grissino-Mayer 1996). The results of linear regressions between standardized tree-ring widths and monthly precipitation data are shown in Fig. 7 for the Los Alamos, Zuni/El Morro (correlation of Zuni precipitation with El Morro tree rings), Mesa Verde, and Chaco/Satan Pass (correlation of Chaco Canyon precipitation with Satan Pass tree rings) areas. These data indicate that tree-ring widths are most highly correlated with cool-season precipitation that begins in October of the previous year and ends in March of the ring year.

The results of linear regressions between standardized tree-ring widths and seasonal and annual time periods are listed in Table 7 for Mesa Verde, Zuni, Los Alamos, and Chaco Canyon. On an annual basis, the August-through-July correlation is somewhat better than the water-year correlation of precipitation with ring width. The correlation of cool-season (October-through-March) precipitation 
Fig. 7 Correlation of meanmonthly precipitation data from weather stations in the four archaeological regions with annual standardized ring widths from trees at or near those stations. The Zuni weather station was correlated with El Morro standardized tree-ring widths and the Chaco Canyon weather station was correlated with Satan Pass standardized tree-ring widths. Cool-season months are contained within the light-gray rectangle and warmseason months are contained within the dark-gray rectangle
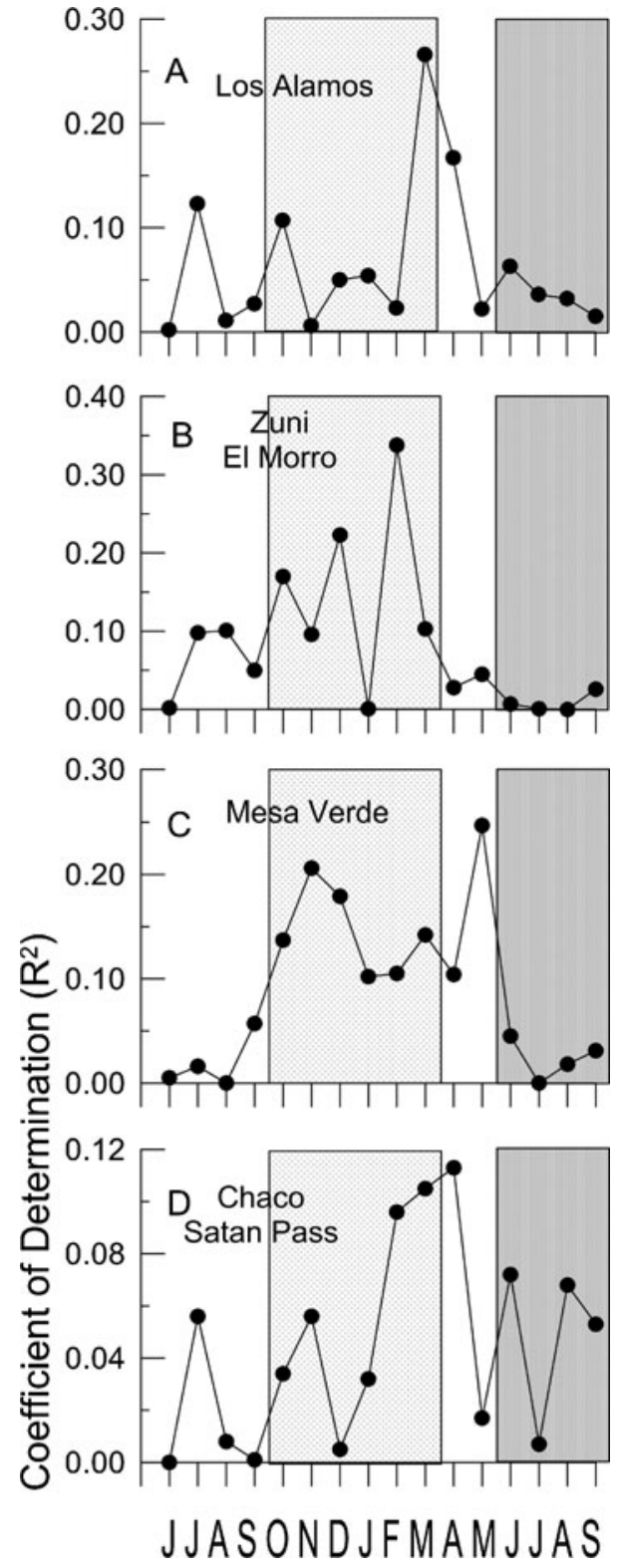

with ring width is quite good for Mesa Verde and Zuni. The weak correlation of August-through-July and water-year precipitation at Chaco and Zuni with ring width may, in part, be due to the large distance $(45-60 \mathrm{~km})$ that separates the tree-ring locations from the weather stations (Table 7). In all four cases, the correlation of summer precipitation with ring width is very low, and the correlation of cool-season precipitation with ring width is higher. 
Because plant growth can be partially determined by the climate of an earlier time period, tree-ring width correlations with prior-year summer and winter precipitation data sets were attempted. In all cases, $R^{2} \leq 0.05$. These results are interpreted to indicate that the growth of ponderosa pine and Douglas fir within the study area is mostly related to winter moisture that falls within the ring year. Note, however, that Los Alamos ring widths correlate to some extent $\left(R^{2}=0.12\right)$ with summer (JJAS) precipitation, indicating that the relatively large amount of summer precipitation received at Los Alamos (Table 4) may influence tree growth.

\section{Soil Chemistry}

\section{Previous Studies of Soil Chemistry}

In Part 1 of this study, the seminal studies of Jon Sandor and his colleagues who dealt with the transport and transformation of $\mathrm{N}$-containing organic matter in the Zuni Reservation were introduced (Homburg et al. 2005; Norton et al. 2003; Norton et al. 2007a, b; Sandor et al. 2007). As part of his thesis, Homburg (2000) measured a variety of chemical and physical parameters in 29 soil profiles from three Zuni field areas (Nutria, Pescado, and Bear Canyon), including $\mathrm{pH}$ (1:1 solution), organic $\mathrm{C}$, total $\mathrm{N}$, and available $\mathrm{P}$ (Olsen-P extraction method). Most of the soil profiles exceeded $2 \mathrm{~m}$ in depth. Histograms and whisker-box plots of those data sets are plotted in Fig. 8. We will return to these data sets in a later section of this paper. Muenchrath et al. (2002) also reported that the $\mathrm{pH}$ of 13 surface $(0-15 \mathrm{~cm})$ soil samples from four Zuni field areas averaged $7.3 \pm 0.5$ with no samples having a $\mathrm{pH}$ $\leq 6.5$.

Decker and Petersen (1987) measured $\mathrm{pH}$, soil organic matter, and available $\mathrm{P}$ on 83 surface soil samples collected from 16 soil types in the Dolores River basin located just to the north of Mesa Verde in Montezuma County, Colorado. Supplementary Table 1 lists those data, which have been summarized in Fig. 9.

\section{New Soil-Chemistry Data}

For this study, 471 soil samples were collected from 161 sites within the four archaeological regions (Figs. 1, 10, 11, 12, and 13). All soil-chemistry data produced in this study are listed in Supplementary Table 2. Because we were nearly always able to sample to a depth of $46 \mathrm{~cm}$ in each of the four archaeological regions, data comparisons between the four regions will often be made using that depth interval, which has been termed the $0-50 \mathrm{~cm}$ interval in figures and tables introduced in this study.

Some field observations Within the Chaco Halo, it was noted that sites along the Rio Chaco downstream from Chaco Canyon were extremely difficult to auger. Usually only the top $46 \mathrm{~cm}$ of soil could be penetrated. In general, floodplain soils within the Canyon are much more compacted than side-valley tributary soils (Supplementary Table 2). At Mesa Verde, unconsolidated loessic soils did not generally reach a depth of more than $50 \mathrm{~cm}$ before either bedrock or caliche 
Table 7 Correlation of Precipitation with Standardized Ring Widths

\begin{tabular}{lllllllll}
\hline $\begin{array}{l}\text { Tree-ring } \\
\text { site }\end{array}$ & $\begin{array}{l}\text { Weather } \\
\text { station }\end{array}$ & Tree (species) & $\begin{array}{l}\text { Distance } \\
(\mathrm{km})\end{array}$ & & $\begin{array}{l}\text { Period } \\
(\text { year })\end{array}$ & $\begin{array}{l}\text { Coefficient of } \\
\text { determination }\left(R^{2}\right)\end{array}$ & \\
\cline { 5 - 9 } & & & & & A-J & WY & ONDJFM & JJAS \\
\hline Mesa Verde & Mesa Verde & Douglas fir & 1 & 68 & 0.67 & 0.60 & 0.57 & 0.01 \\
El Morro & Zuni & Ponderosa pine & 45 & 23 & 0.27 & 0.19 & 0.56 & 0 \\
Los Alamos & Los Alamos & Douglas fir & 1 & 53 & 0.41 & 0.33 & 0.33 & 0.12 \\
Satan Pass & Chaco Canyon & Douglas fir & 60 & 44 & 0.25 & 0.15 & 0.16 & 0 \\
\hline
\end{tabular}

Standardized ring widths were obtained from the NOAA paleoclimatology website except for the Navajo Canyon and Mesa Verde ring widths, which were taken from Meko et al. (2007). Precipitation data were obtained from the Western Regional Climate Center (http://www.wrcc.dri.edu/). Distance=distance between tree-ring site and weather station

$A-J$ previous August through current July; $W Y$ water year which starts on October 1 of previous year; ONDJFM October, November, December, January, February, March; JJAS June, July, August, September

(Arrhenius and Bonatti 1965) was encountered (Supplementary Table 2). Soils in the Zuni field systems were remarkably easy to auger to a depth of $1 \mathrm{~m}$. Depth of soil penetration at Bandelier was highly variable with about two thirds of the auger holes reaching depths $\geq 76 \mathrm{~cm}$.

\section{Zuni Soils (upper $50 \pm 10 \mathrm{~cm}$ )}
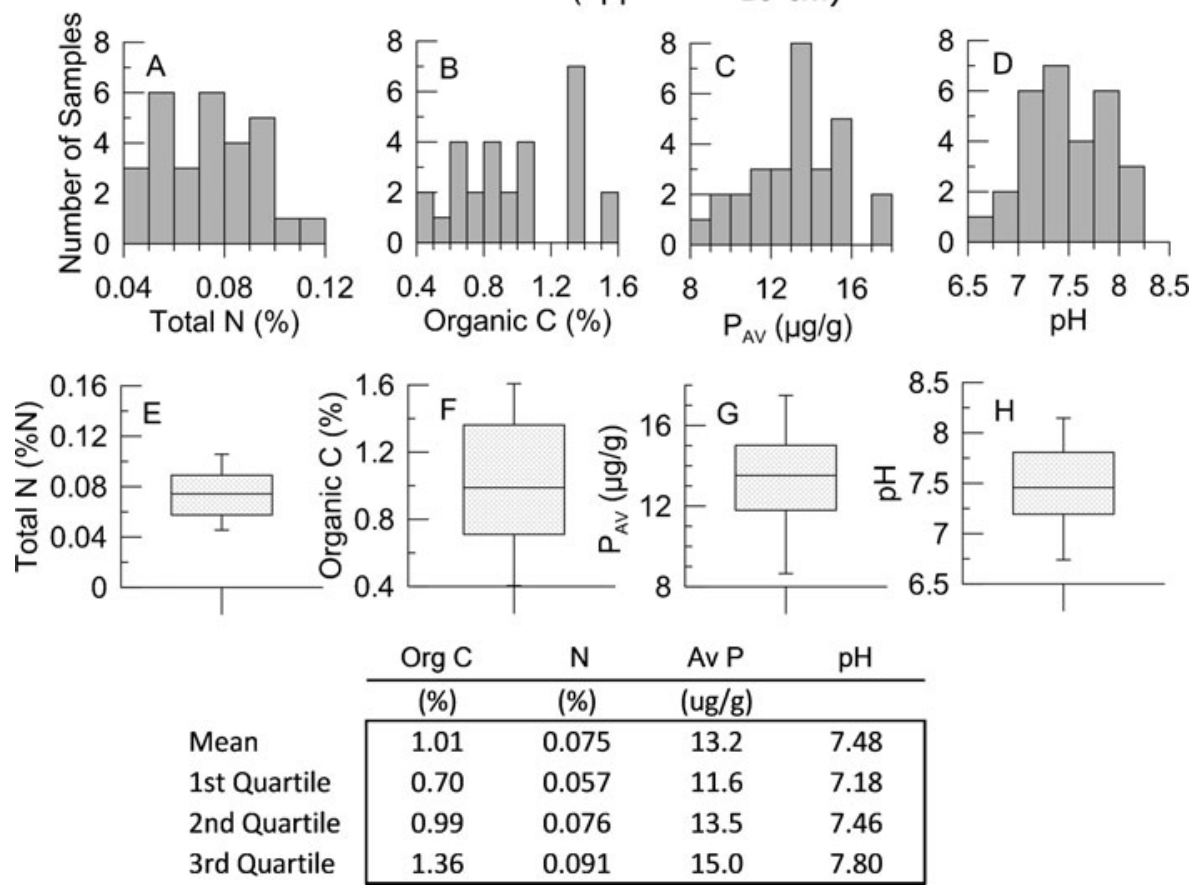

Fig. 8 Total $\mathrm{N}$, organic $\mathrm{C}$, available $\mathrm{P}\left(\mathrm{P}_{\mathrm{AV}}\right)$, and $\mathrm{pH}$ in the top $50 \mathrm{~cm}$ of Zuni soils. Total organic $\mathrm{N}$ values are nearly equivalent to total $\mathrm{N}$ values (data from Homburg 2000) 
Dolores Soils (surface)
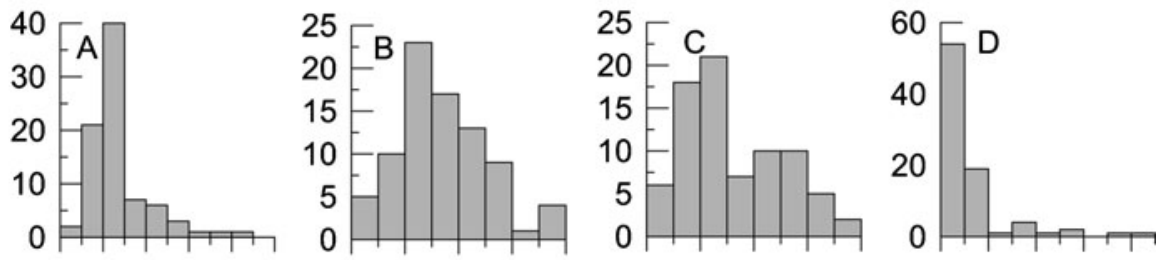

\section{$\begin{array}{llllll}0 & 1 & 2 & 3 & 4 & 5\end{array}$} Organic C (\%)

$0 \quad 10203040$ $P_{A V}(\mu g / g)$

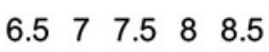

$\mathrm{pH}$ $\begin{array}{lllll}0 & 1 & 2 & 3 & 4\end{array}$

EC (dS/m)
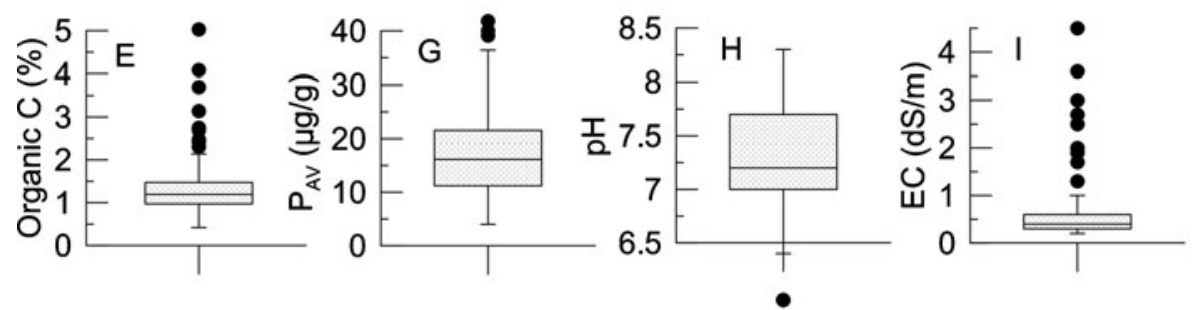

\begin{tabular}{lcccc} 
& \multicolumn{1}{c}{ Org C } & $\mathrm{P}_{\mathrm{AV}}$ & $\mathrm{pH}$ & \multicolumn{1}{c}{$\mathrm{EC}$} \\
\cline { 2 - 5 } & \multicolumn{1}{c}{$(\%)$} & $(\mathrm{ug} / \mathrm{g})$ & & $(\mathrm{dS} / \mathrm{m})$ \\
\cline { 2 - 5 } Mean & 1.38 & 17.4 & 7.29 & 0.71 \\
1st Quartile & 0.94 & 11.2 & 7.00 & 0.30 \\
2nd Quartile & 1.19 & 16.2 & 7.20 & 0.40 \\
3rd Quartile & 1.42 & 20.7 & 7.70 & 0.60 \\
\cline { 2 - 5 } & & & &
\end{tabular}

Fig. 9 Organic $\mathrm{C}$, available $\mathrm{P}\left(P_{A V}\right), \mathrm{pH}$, and electrical conductivity $(E C)$ in the top $15 \mathrm{~cm}$ of Dolores valley soils (data from Decker and Petersen 1987)

Soil moisture Soils in the Chaco Halo, Zuni, and Bandelier areas have median moisture values ranging from about $5 \%$ to $8 \%$; however, Mesa Verde soils are extremely dry with a median moisture of $<1 \%$ in the upper $50 \mathrm{~cm}$ of soil (Table $8^{2}$, Fig. 14). Daily precipitation values for the 180 days prior to sampling at each archaeological area are shown for weather stations nearest each area in Fig. 15. The data indicate that Bandelier and Zuni soils may have benefited from precipitation events that occurred about 10 days prior to sampling (Fig. 15b, f); however, substantial precipitation did not occur within the Chaco Halo for at least a month prior to sampling (Fig. 15a, c, d). Despite its low soil moisture values, Mesa Verde received substantial precipitation during the month preceding its sampling. This suggests that the loessic soil that caps Mesa Verde is well drained and probably lacks appreciable amounts of water-adsorbing clay minerals (Arrhenius and Bonatti 1965).

Electrical conductivity Maize productivity begins to decrease when EC reaches $\sim 1.5 \mathrm{dS} / \mathrm{m}$. Soil ECs do not present a threat to the cultivation of maize at Mesa Verde, Zuni, or at Bandelier; however, some of the soils within Chaco Canyon near Penasco Blanco, Casa Chiquita, and Fajada Buttes have elevated EC values

\footnotetext{
${ }^{2}$ Table 8 was constructed in order to compare soil parameters for all four archaeological regions; i.e., data from the top 50 (actually 46) $\mathrm{cm}$ of soil were available for each of the four regions.
} 


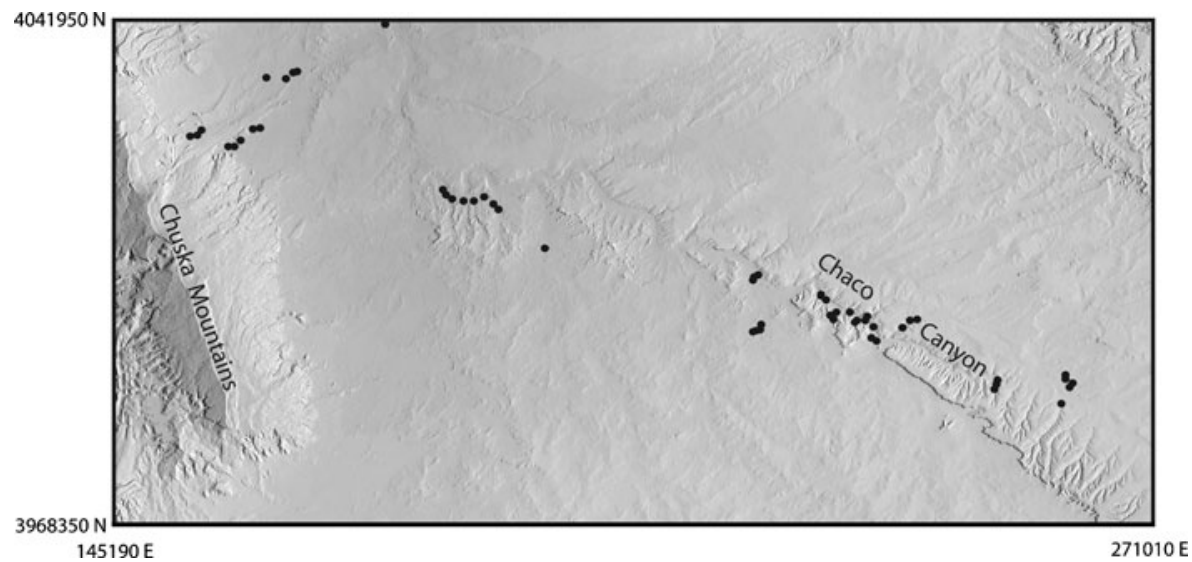

Fig. 10 Soil-sampling sites within the Chaco Halo

(Supplementary Table 2; Tables 8, 9; Fig. 16). Elevated EC values also occur downstream from the Canyon at Kin Klizhin, the Great Bend, Indian Creek, and Willow Canyon, upstream from the canyon at Pueblo Pintado, and in the Two Grey Hills area of the Chuska Slope (Supplementary Table 2). In particular, Chaco Canyon and Rio Chaco floodplain soils tend to have much higher salinities than Chaco Canyon side-valley soils (Fig. 17), probably as a result of evaporative concentration of shallow groundwater or the evaporative concentration of runoff from side-valley tributaries.

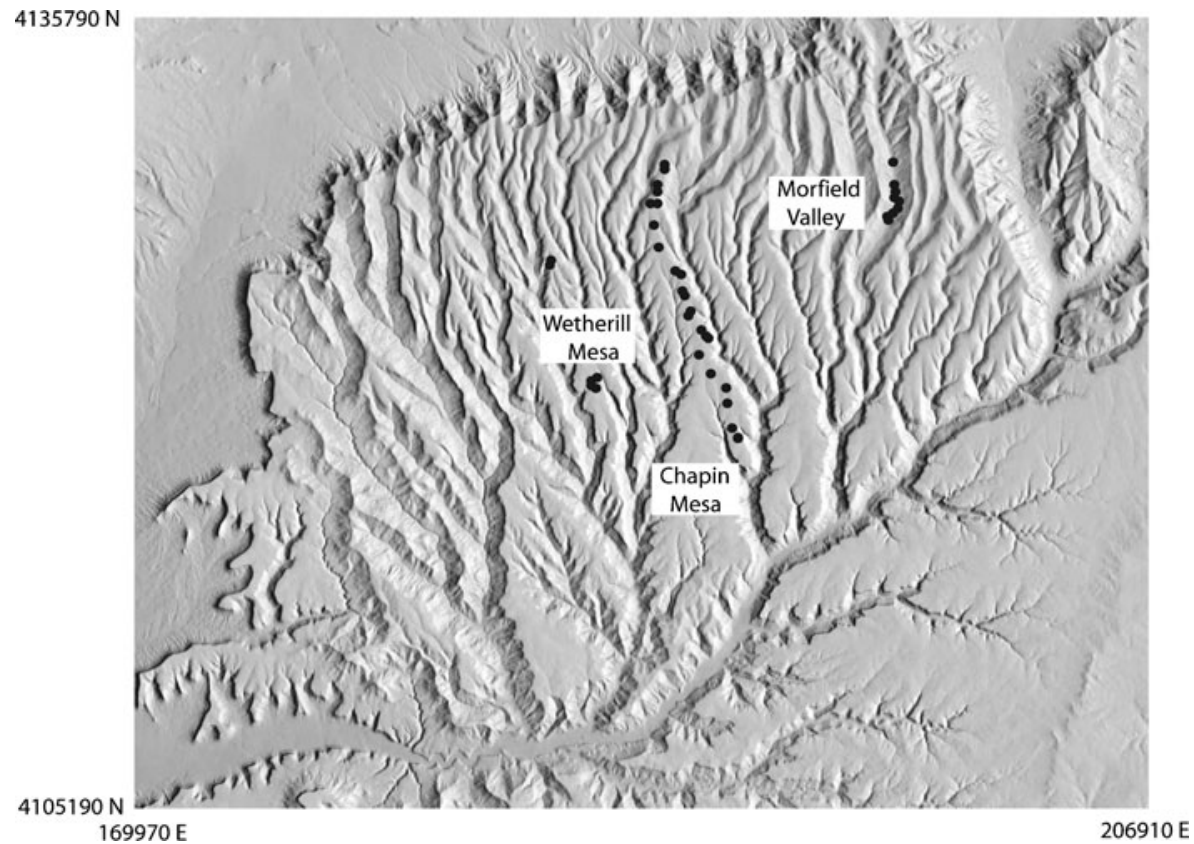

Fig. 11 Soil-sampling sites at Mesa Verde National Park 


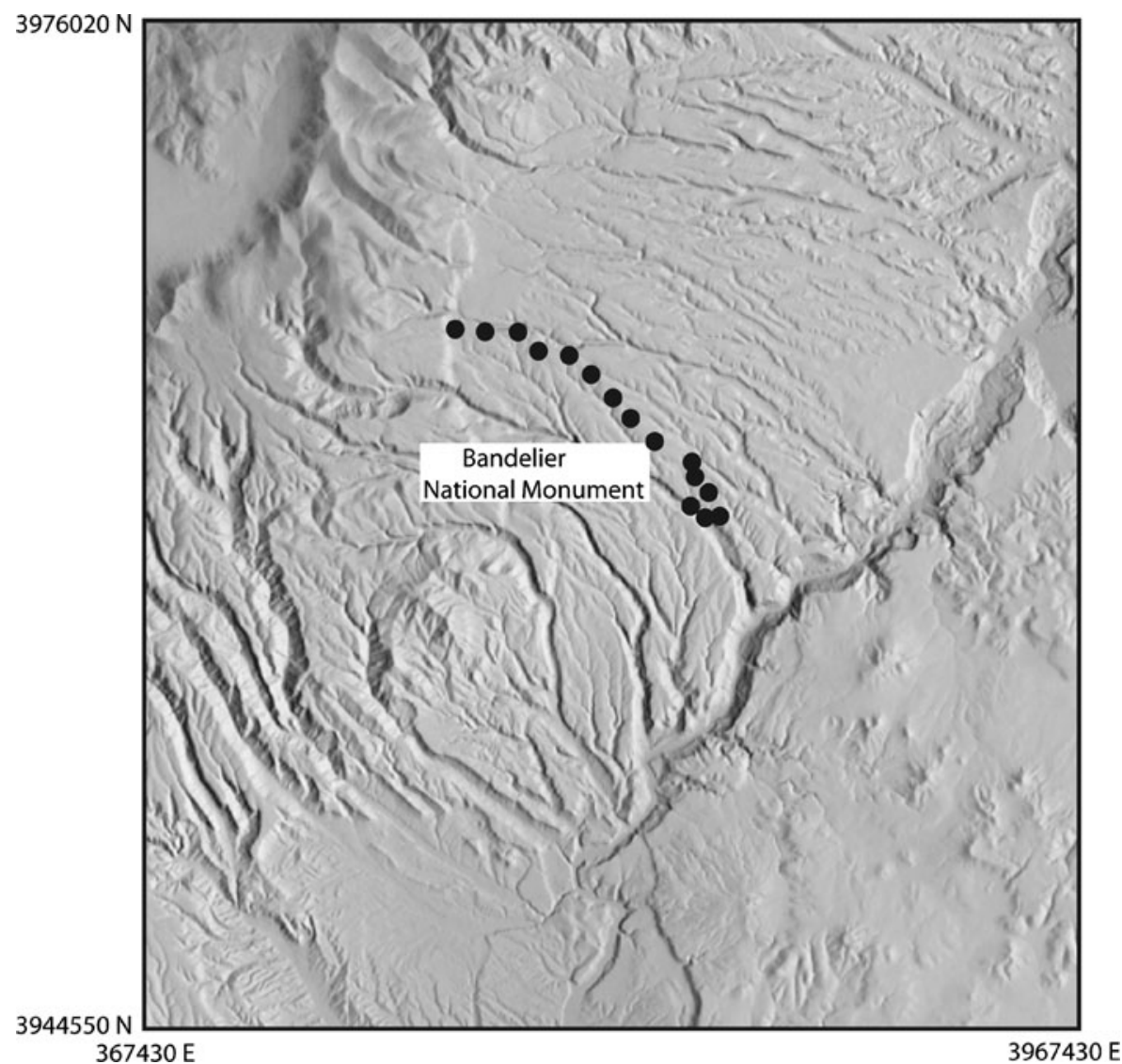

Fig. 12 Soil-sampling transect at Bandelier National Monument, Pajarito Plateau

$p H$ The optimal $\mathrm{pH}$ range for available $\mathrm{P}$ and $\mathrm{N}$ is 6.0-6.5. Soil $\mathrm{pH}$ at Mesa Verde and Bandelier is near optimal whereas Zuni values are slightly elevated; however, $\mathrm{pH}$ values in Chaco Halo soils are $\sim 2$ units higher (100 times more basic) than optimal (Supplementary Table 2; Tables 8, 9; Fig. 18).

Total inorganic carbon The presence of calcium carbonate within a soil will tend to buffer the $\mathrm{pH}$ of the soil water, maintaining relatively high (basic) values. Chaco Halo soils (Table 8, Fig. 19), especially those within the Chuska Slope (Table 9), contain substantial amounts of TIC relative to the other archaeological areas. The elevated TIC percentages of Chaco Halo soils are reflected in the elevated $\mathrm{pH}$ values of the same soils (Table 8, Fig. 18a).

Available phosphorus $\left(P_{A V}\right)$ In Part 1 of this study (Benson 2010), we learned that a $\mathrm{P}_{\mathrm{AV}}$ value of 11-14 $\mu \mathrm{g} / \mathrm{g}$ was recommended for Midwestern maize grown at a density of 32,000 plants/ac, and that if this value was scaled by ratioing Southwestern and Midwestern maize root densities, a value of approximately 1.5$2.0 \mu \mathrm{g} / \mathrm{g} \mathrm{P}_{\mathrm{AV}}$ would suffice for Southwestern maize planted at a density of 2,000 


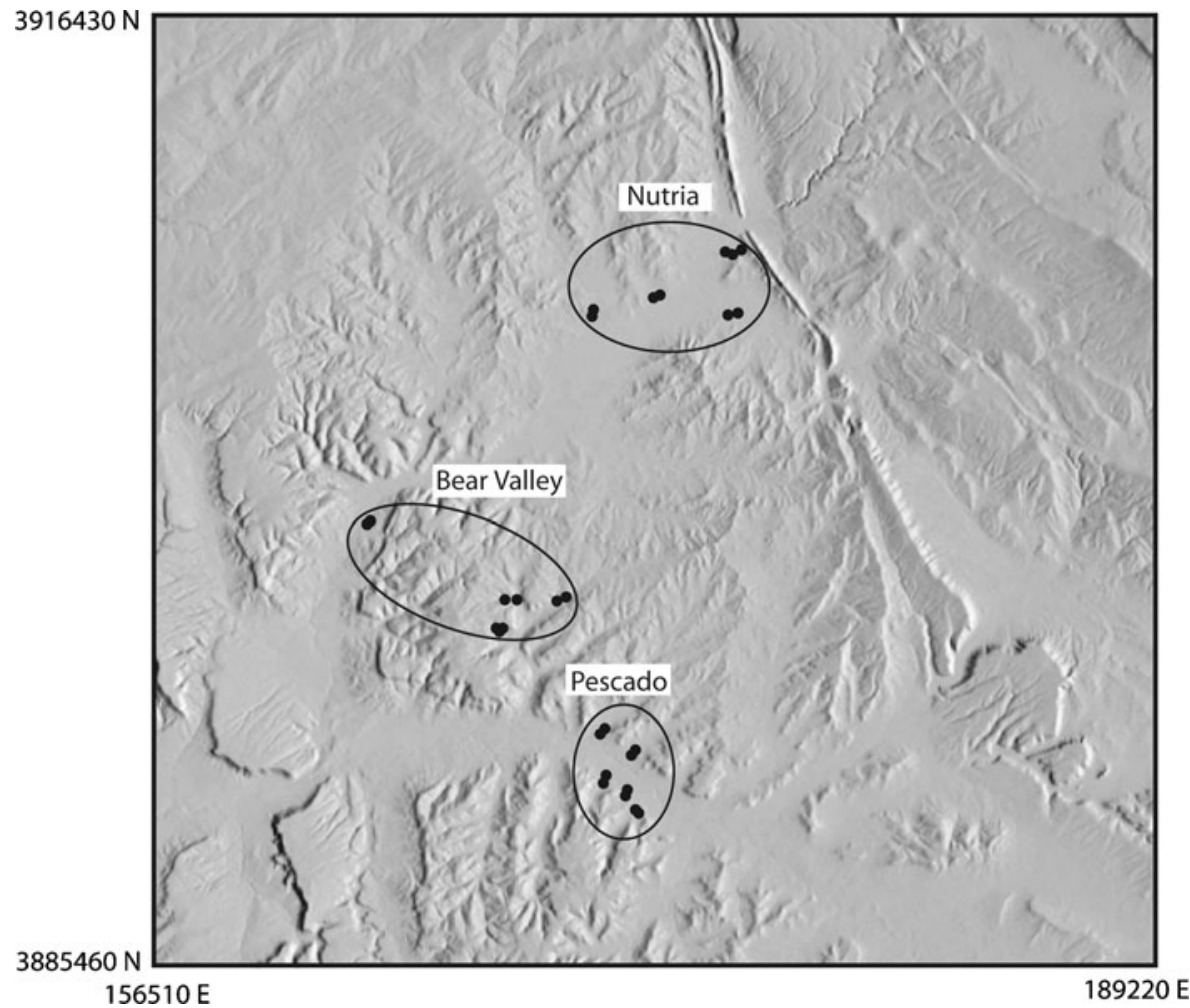

Fig. 13 Soil-sampling sites within the three field systems at Zuni

plants/ac. Generally speaking, soils within the four archaeological regions have sufficient $\mathrm{P}_{\mathrm{AV}}$ values for the production of maize (Table 8, Fig. 20); however, $\mathrm{P}_{\mathrm{AV}}$ is less than optimal for soils at the Casa del Rio site along the Rio Chaco (Supplementary Table 2) and for about one quarter of the soils at Bandelier (Table 9).

Available nitrogen $\left(\mathrm{NO}_{3}-\mathrm{N}\right)$ We also learned in Part 1 of this study that modern agronomists suggest an optimal $\mathrm{NO}_{3}-\mathrm{N}$ range of $20-25 \mu \mathrm{g} / \mathrm{g}$ for Midwestern maize root densities which scales to $3-4 \mu \mathrm{g} / \mathrm{g}$ for Native American Southwestern maize root densities. Mesa Verde has only a few sites (principally in Morfield ValleySupplementary Table 2) that have $\mathrm{NO}_{3}-\mathrm{N}$ values that exceed $3 \mu \mathrm{g} / \mathrm{g}$, and essentially all the Bandelier soils have $\mathrm{NO}_{3}-\mathrm{N}$ values $<2 \mu \mathrm{g} / \mathrm{g}$ (Tables 8, 9; Fig. 21). In addition, at least half of the Zuni soils have non-optimal $\mathrm{NO}_{3}-\mathrm{N}$ values (Tables 8, 9; Fig. 21). In contrast, the Chaco Halo has many sites with substantial $\mathrm{NO}_{3}-\mathrm{N}$ values (Table 8, Fig. 21), with some sites along the Rio Chaco having extreme values (Table 9), e.g., Kin Klizhin, Great Bend, and Willow Canyon (Supplementary Table 2). The latter Rio Chaco sites also are associated with elevated ECs (Supplementary Table 2), which suggests that the $\mathrm{NO}_{3}-\mathrm{N}$ is part of the salt load associated with these mostly floodplain soils. In fact, $61 \%$ (36 out of 59) of the soils within the Chaco Halo, having an $\mathrm{EC}>1$, also have $\mathrm{NO}_{3}-\mathrm{N}$ values $>10$ (Supplementary Table 2). This implies that most of the elevated $\mathrm{NO}_{3}-\mathrm{N}$ values are 
Table 8 Chemistry of the Top $50 \mathrm{~cm}$ of Soils in the Four Archaeological Regions

\begin{tabular}{|c|c|c|c|c|c|c|c|c|}
\hline & Chaco Halo & Mesa Verde & Zuni & Bandelier & Chaco Halo & Mesa Verde & Zuni & Bandelier \\
\hline & \multicolumn{4}{|c|}{ Soil moisture (\%) } & \multicolumn{4}{|c|}{ Total organic C $(\%)$} \\
\hline 1st quartile & 4.03 & 0.59 & 5.71 & 5.61 & 0.325 & 0.570 & 0.731 & 0.433 \\
\hline 2nd quartile & 5.14 & 0.76 & 6.89 & 7.91 & 0.529 & 0.735 & 0.964 & 0.637 \\
\hline 3rd quartile & 7.68 & 0.87 & 8.15 & 9.48 & 0.831 & 1.056 & 1.217 & 0.767 \\
\hline Mean & 6.16 & 0.75 & 7.08 & 8.20 & 0.643 & 1.058 & 1.006 & 0.628 \\
\hline & \multicolumn{4}{|l|}{$\mathrm{pH}$} & \multicolumn{4}{|l|}{$\mathrm{NO}_{3}-\mathrm{N}(\mu \mathrm{g} / \mathrm{g})$} \\
\hline 1st quartile & 8.1 & 6.2 & 7.1 & 6.5 & 2.7 & 0.26 & 0.80 & 0.36 \\
\hline 2nd quartile & 8.3 & 6.6 & 7.4 & 6.8 & 4.9 & 0.52 & 1.30 & 0.54 \\
\hline 3rd quartile & 8.8 & 7.1 & 7.6 & 7.2 & 14.4 & 1.31 & 3.50 & 1.23 \\
\hline \multirow[t]{2}{*}{ Mean } & 8.2 & 6.4 & 7.2 & 6.7 & 38.5 & 1.20 & 2.26 & 0.75 \\
\hline & \multicolumn{4}{|c|}{ Electrical conductivity $(\mathrm{dS} / \mathrm{m})$} & \multicolumn{4}{|c|}{ Total organic N $(\%)$} \\
\hline 1st quartile & 0.451 & 0.446 & 0.281 & 0.109 & 0.028 & 0.051 & 0.058 & 0.035 \\
\hline 2nd quartile & 0.662 & 0.571 & 0.375 & 0.142 & 0.044 & 0.060 & 0.073 & 0.057 \\
\hline 3rd quartile & 1.727 & 0.724 & 0.463 & 0.195 & 0.070 & 0.084 & 0.093 & 0.061 \\
\hline \multirow[t]{2}{*}{ Mean } & 1.923 & 0.623 & 0.393 & 0.150 & 0.050 & 0.076 & 0.077 & 0.050 \\
\hline & \multicolumn{4}{|c|}{ Total inorganic $\mathrm{C}(\%)$} & \multicolumn{4}{|c|}{ Available $\mathrm{P}(\mu \mathrm{g} / \mathrm{g})$} \\
\hline 1st quartile & 0.070 & 0.001 & 0.002 & 0.000 & 3.8 & 6.5 & 6.0 & 1.5 \\
\hline 2nd quartile & 0.159 & 0.005 & 0.015 & 0.009 & 5.0 & 9.0 & 7.3 & 2.1 \\
\hline 3rd quartile & 0.327 & 0.020 & 0.065 & 0.014 & 7.4 & 13.0 & 8.5 & 3.5 \\
\hline Mean & 0.229 & 0.214 & 0.085 & 0.008 & 6.1 & 11.8 & 8.3 & 4.0 \\
\hline
\end{tabular}
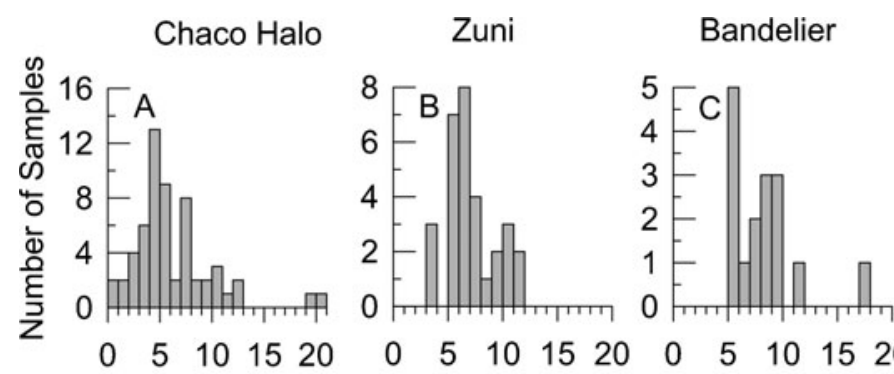

Mesa Verde

\section{Soil Moisture (\%) Upper $50 \mathrm{~cm}$}
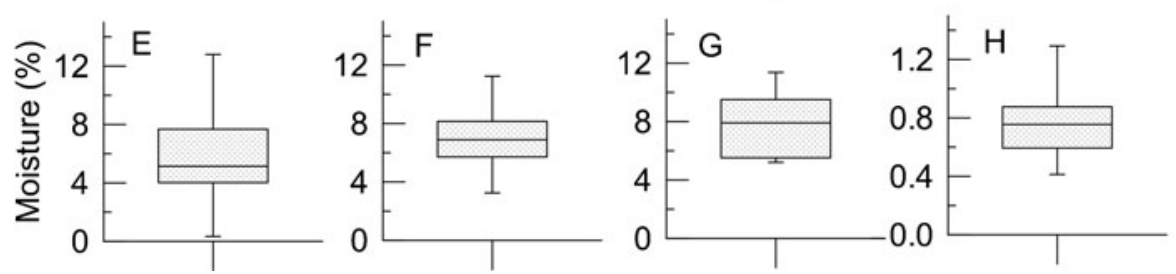

Fig. 14 Soil moisture in the top $50 \mathrm{~cm}$ of soils within the four archaeological regions 

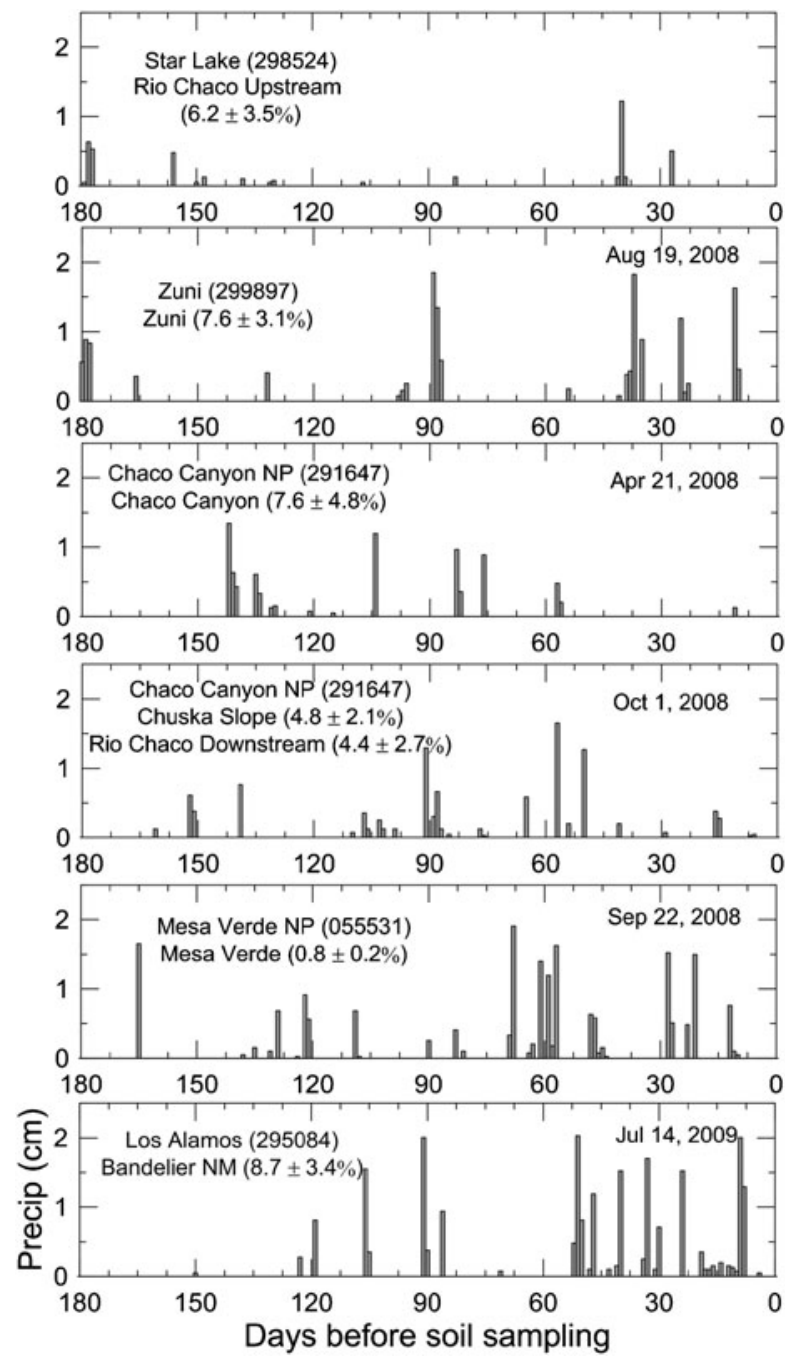

Fig. 15 Daily precipitation amounts (cm) 180 days prior to soil sampling. Date of soil sampling shown in upper right of each panel. Average soil-moisture values at the time of sampling for areas that a weather station is assumed to proxy for are shown just below weather station name and number

associated with soils whose salinities prevent root penetration. Although $\mathrm{NO}_{3}-\mathrm{N}$ is abundant, the roots of maize and other saline-intolerant plants cannot access this $\mathrm{N}$ reservoir.

Total organic carbon and total organic $N$ The four archaeological regions have different amounts of TOC - from highest to lowest: Zuni, Mesa Verde, Bandelier, and the Chaco Halo (Table 8, Fig. 22). Even though the $\mathrm{C} / \mathrm{N}$ ratio is variable within each of the four archaeological regions (Supplementary Table 2), generally speaking the relative abundance of organic $\mathrm{N}$ parallels that of TOC (Table 8, compare Fig. 22 with Fig. 23). 


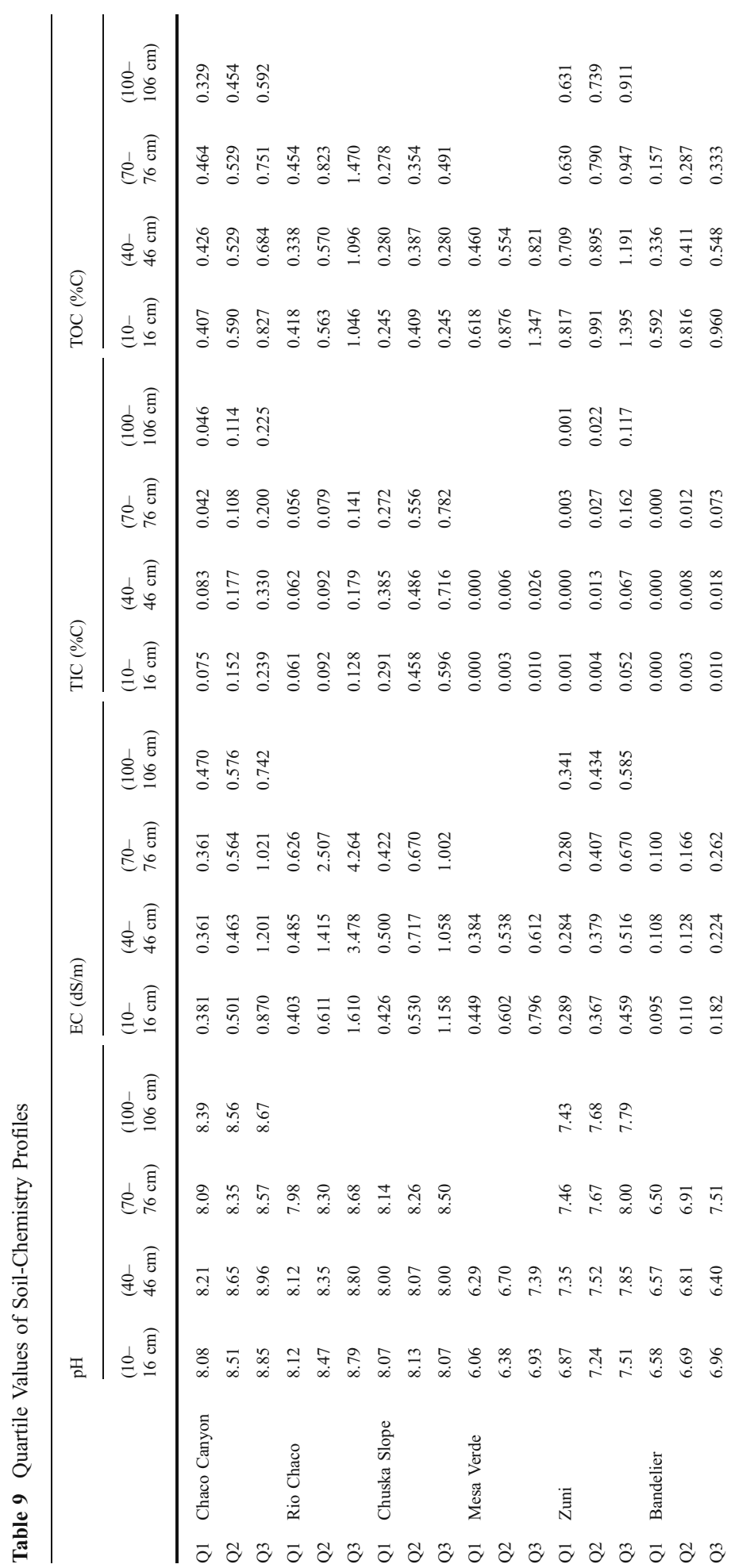




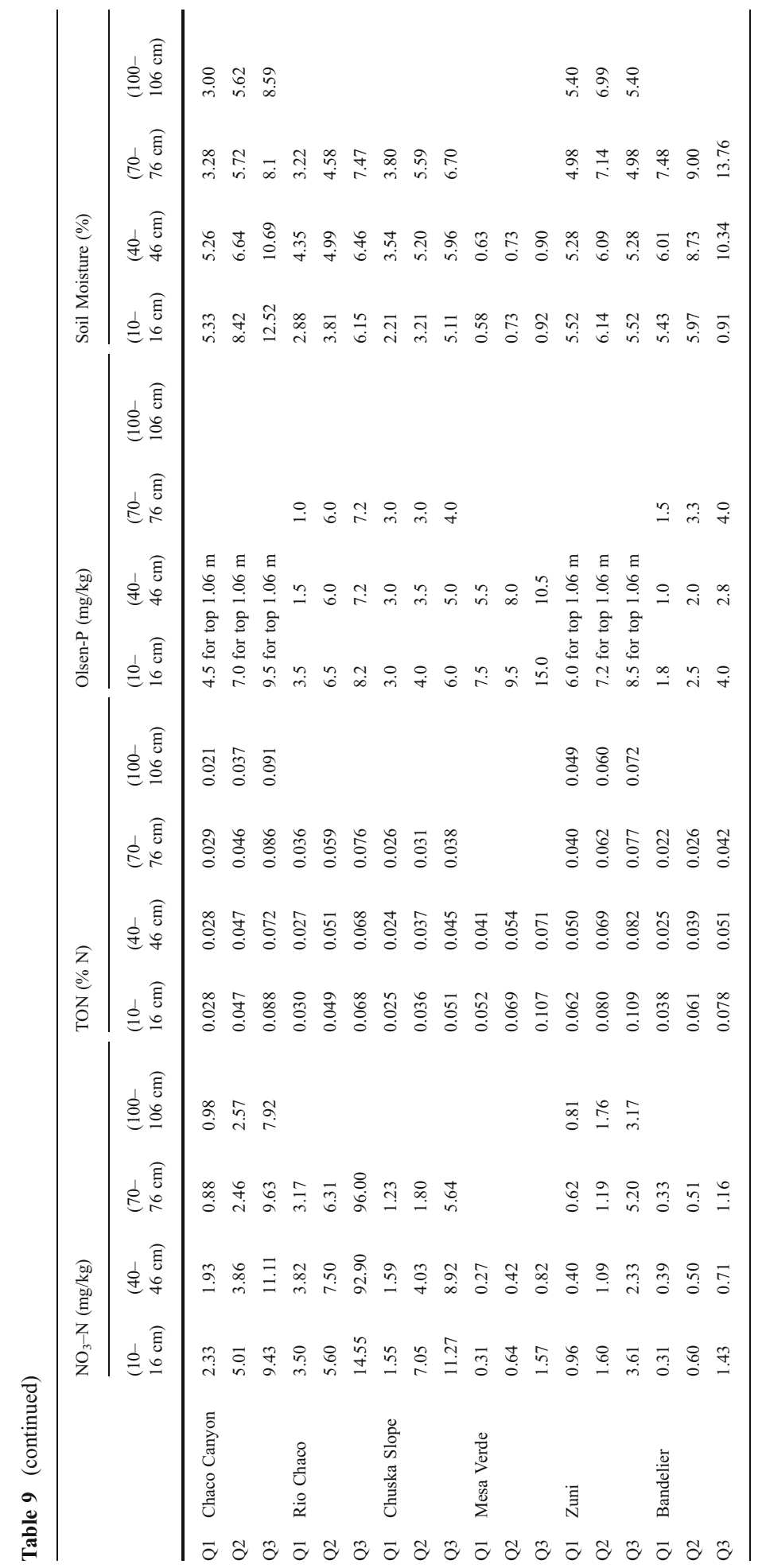




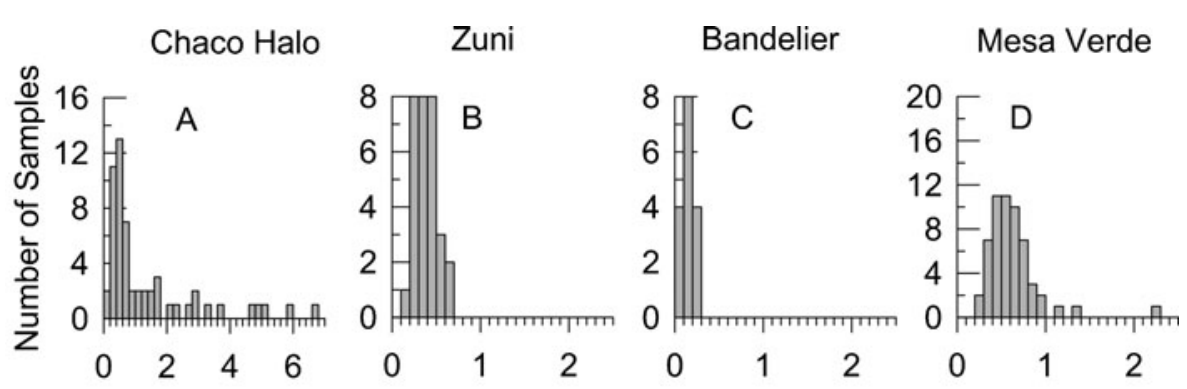

Electrical Conductivity (dS/m) Upper $50 \mathrm{~cm}$
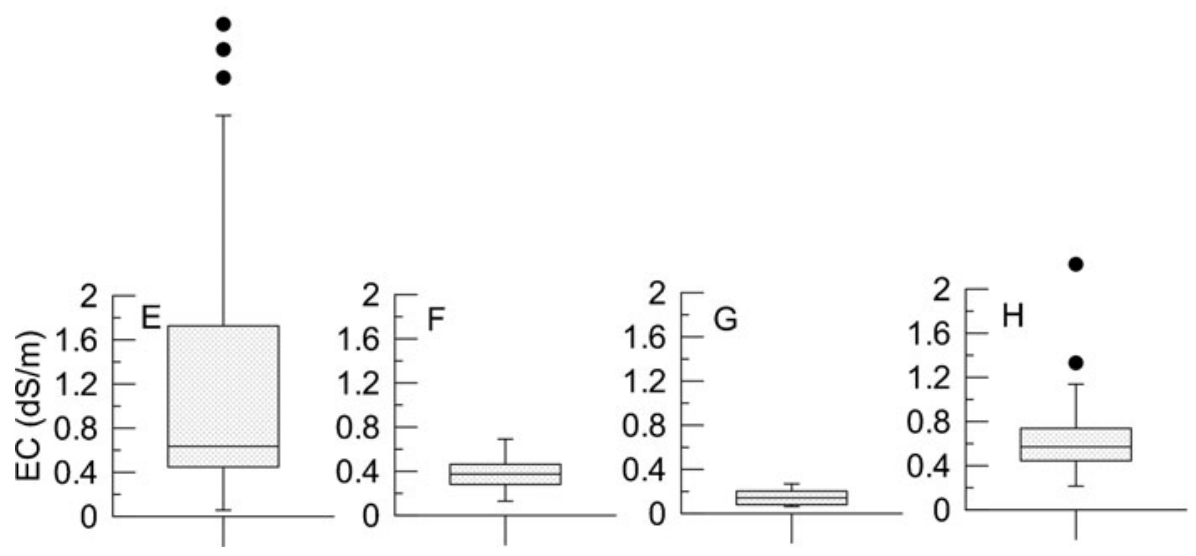

Fig. 16 Electrical conductivity for the top $50 \mathrm{~cm}$ of soil within the four archaeological regions

Soils within the Chaco Halo, Chaco Canyon, and soils along the Rio Chaco, upstream and downstream from the Canyon, have nearly the same distribution of total organic N (TON) whereas Chuska Slope soils have substantially less TON (Table 9, Fig. 24). Within the Mesa Verde region, Morfield Valley contains substantially more TON than the two mesa systems (Wetherill and Chapin) that were

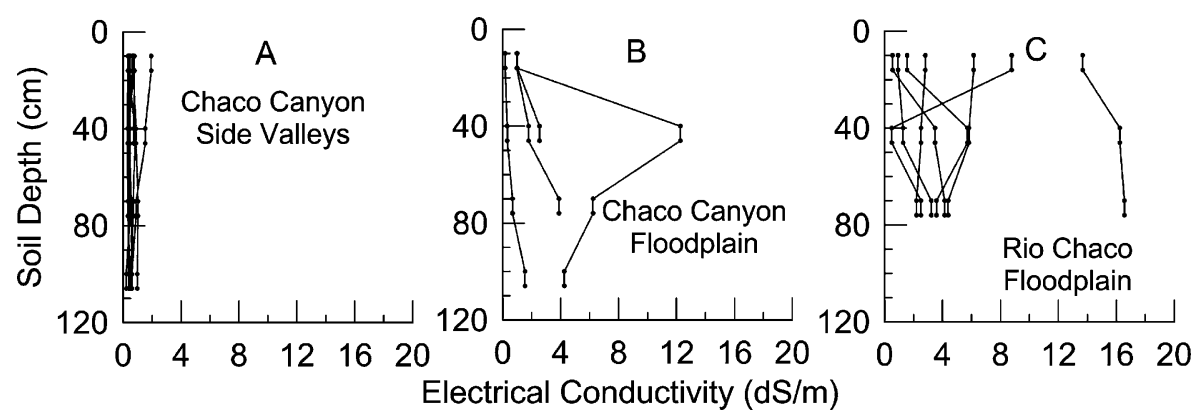

Fig. 17 Electrical conductivity (EC) for floodplain and side-valley sites along the Rio Chaco, including the Chaco Canyon reach 

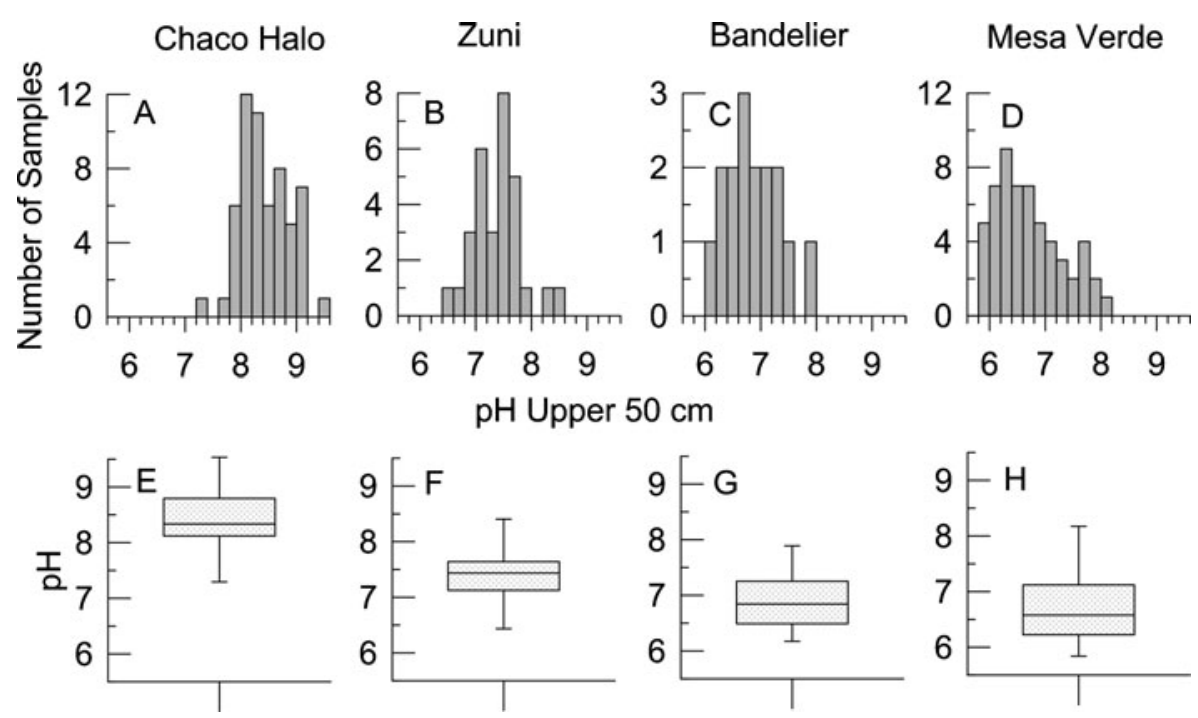

Fig. $18 \mathrm{pH}$ in the upper $50 \mathrm{~cm}$ of soils within the four archaeological regions

sampled (Fig. 25). The three Zuni field areas (Bear Canyon, Nutria, and Pescado) have nearly the same TON distributions (Fig. 26).

Mineralization of organic $N$ In Part 1 of this study, the mineralization of organic $\mathrm{N}$ to $\mathrm{NH}_{4}{ }^{+}$and its bacterial transformation to $\mathrm{NO}_{3}-\mathrm{N}$ (both of which are biologically
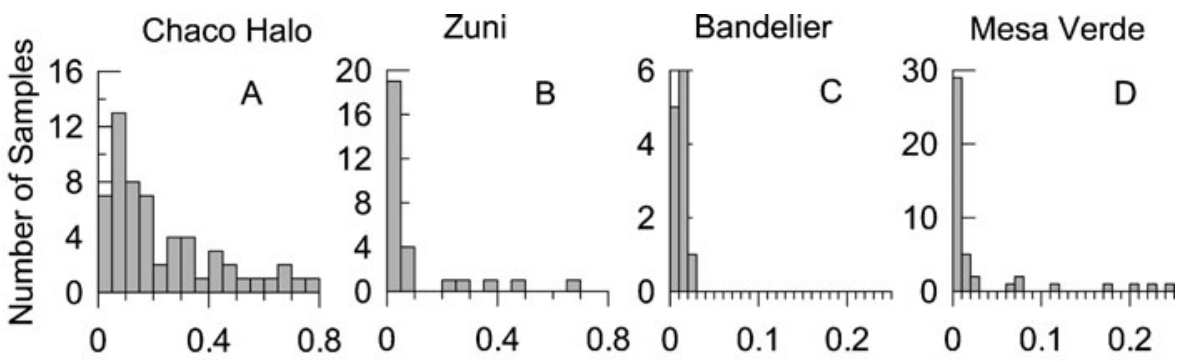

TIC (\%C) Upper $50 \mathrm{~cm}$
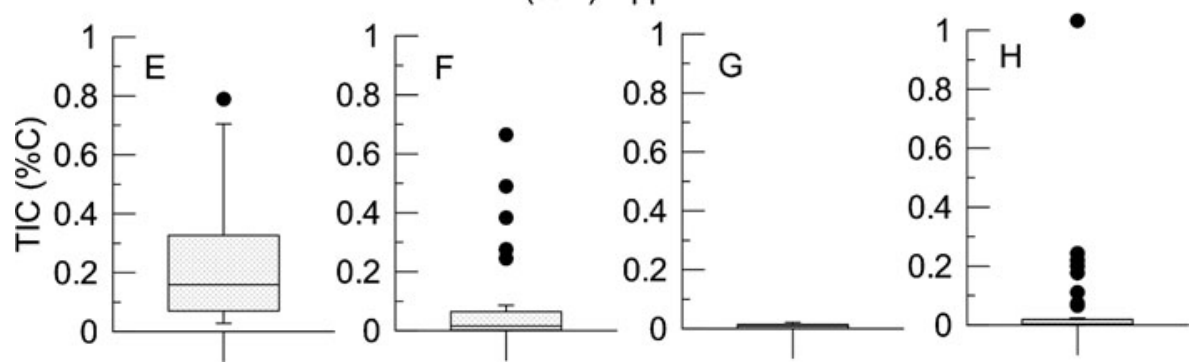

Fig. 19 Total inorganic carbon (TIC) concentrations within the upper $50 \mathrm{~cm}$ of soil within the four archaeological regions 


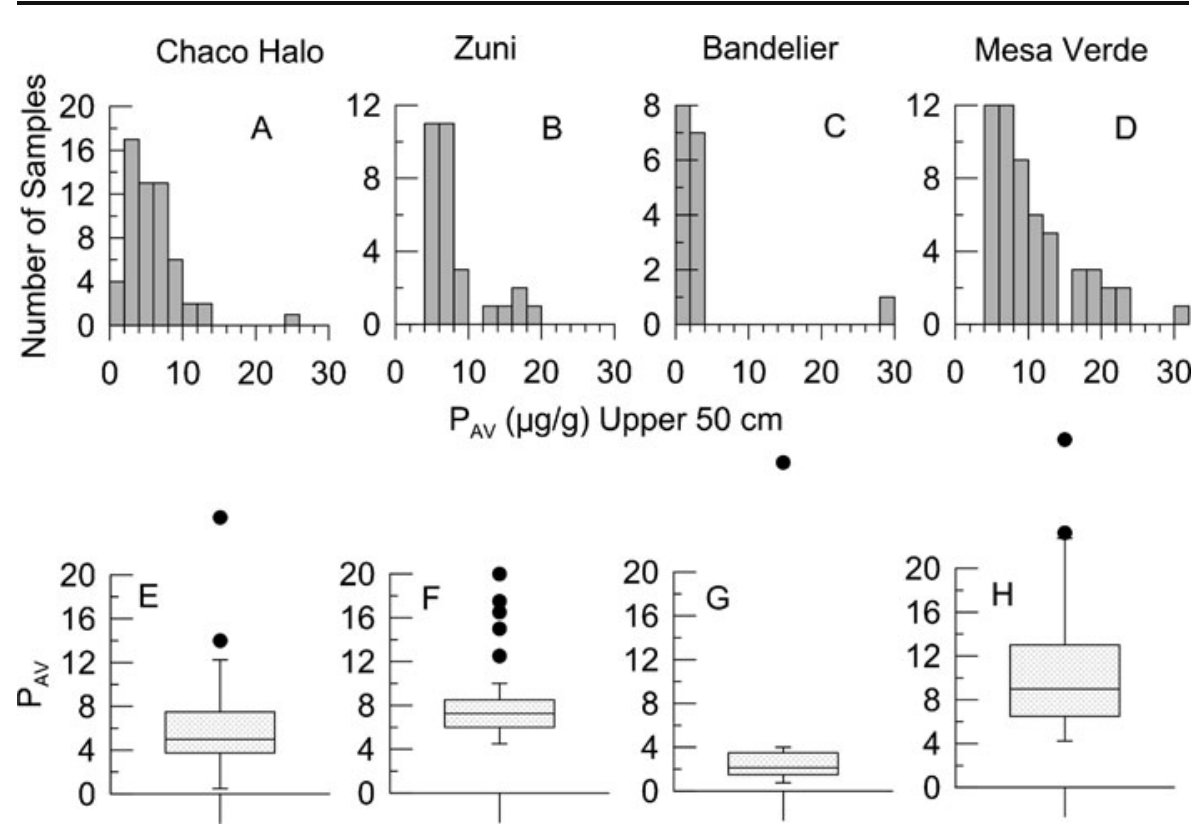

Fig. 20 Available phosphorus $\left(P_{A V}\right)$ in the upper $50 \mathrm{~cm}$ of soils within the four archaeological regions (determined by the Olsen-P method)

available to maize) were discussed. Given that most of the maize root system lies within the upper $50 \mathrm{~cm}$ of the soil and that labile organic $\mathrm{N}$ decreases exponentially with depth, it will be assumed, as it was in Part 1 , that only $50 \%$ of the organic $\mathrm{N}$ within the upper $50 \mathrm{~cm}$ of the soil can be rapidly mineralized.
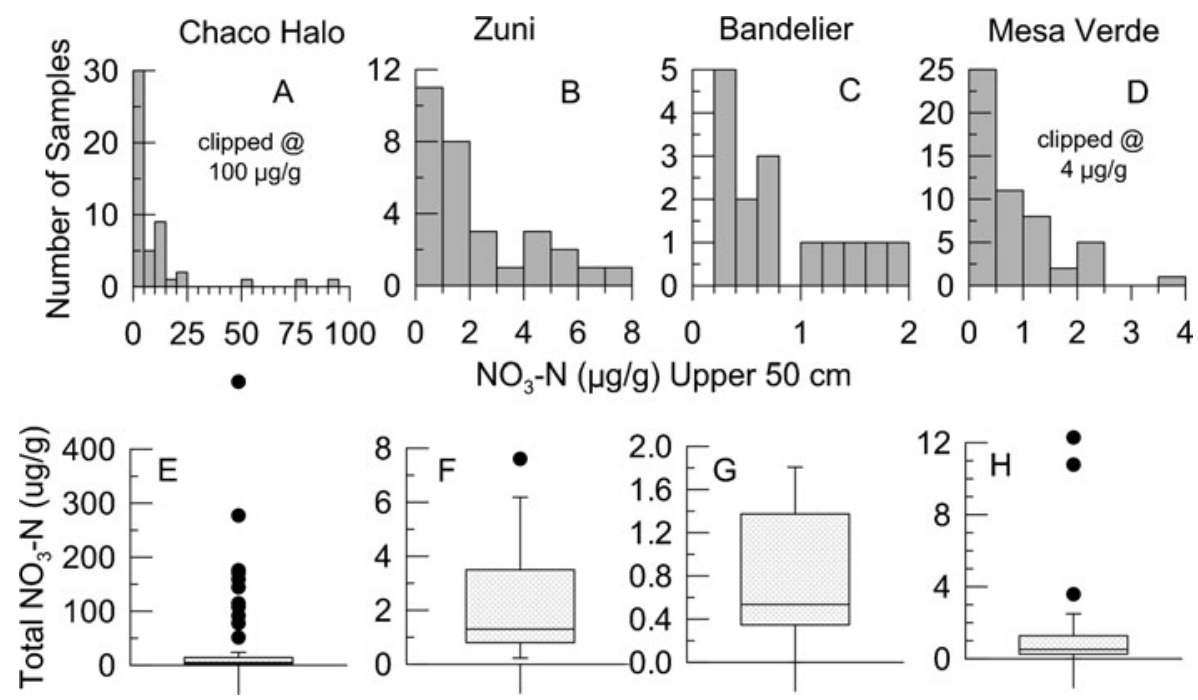

Fig. $21 \mathrm{NO}_{3}-\mathrm{N}$ concentrations in the upper $50 \mathrm{~cm}$ of soil in the four archaeological regions. For illustration purposes, two of the histograms have been "clipped" and do not display the most extreme outlier values 

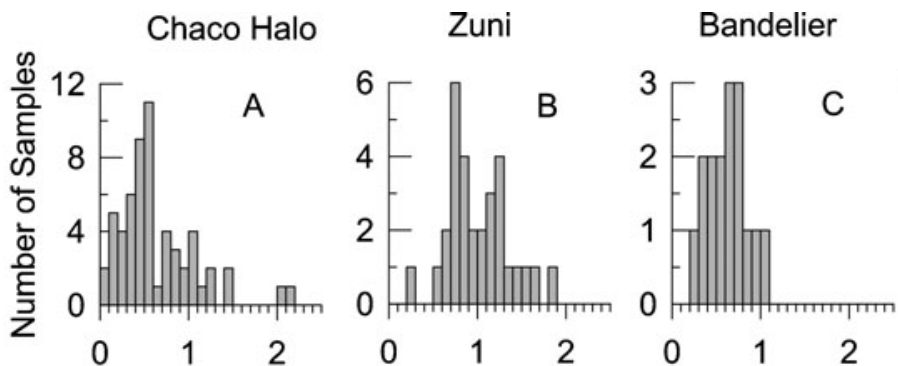

Mesa Verde

Total Organic Carbon (\%C) Upper $50 \mathrm{~cm}$
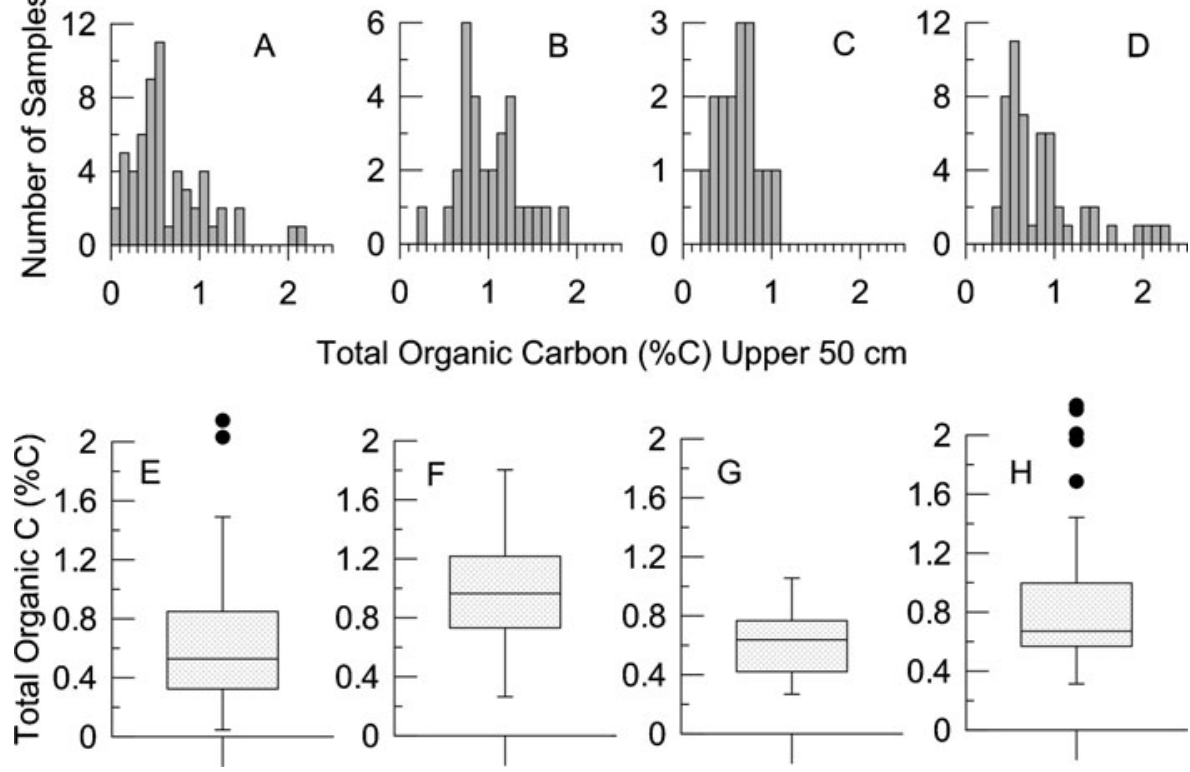

Fig. 22 Total organic carbon (TOC) concentrations in the upper $50 \mathrm{~cm}$ of soil within the four archaeological regions

The results of agricultural productivity and "field life" calculations, using Equation 0.9 in Part 1 of this study, are displayed in Table 10. These calculations assume that $14.85 \mathrm{~g}$ of $\mathrm{NO}_{3}-\mathrm{N}$ need to be produced within a $50-\mathrm{cm}$ soil frustum that encloses the root systems of 4.5 maize plants in order to produce a $10 \mathrm{bu} / \mathrm{ac}$ crop.
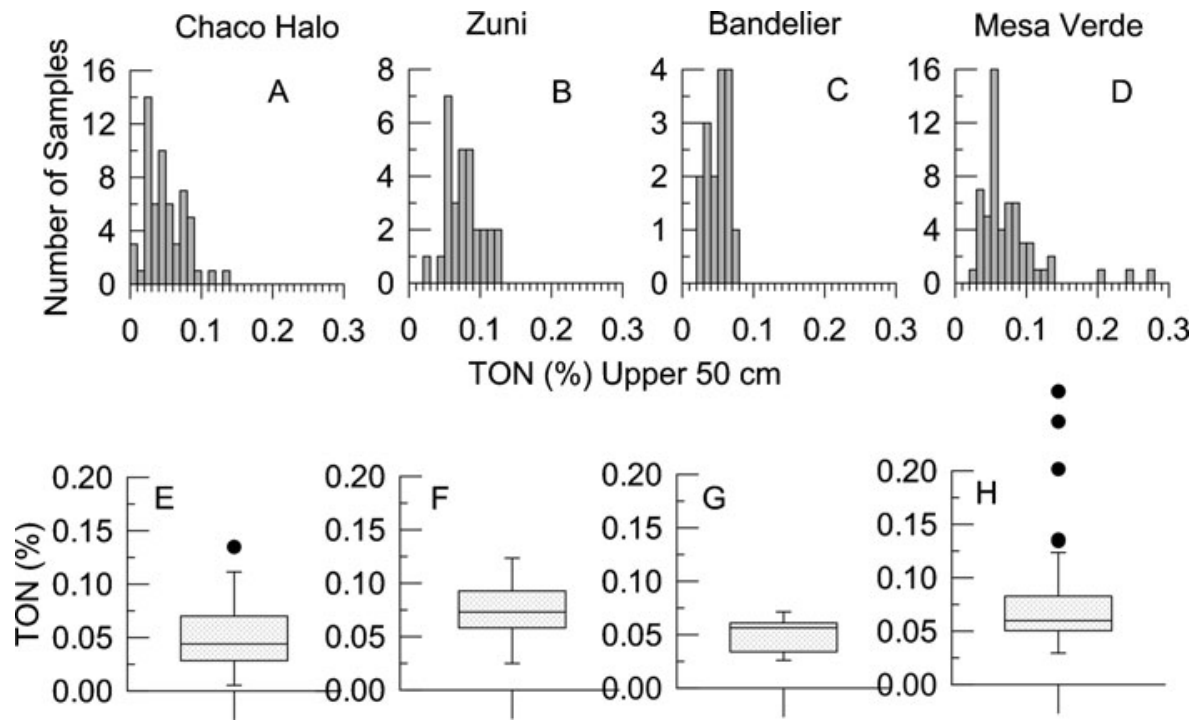

Fig. 23 Total organic nitrogen $(T O N)$ concentrations in the upper $50 \mathrm{~cm}$ of soil within the four archaeological regions 

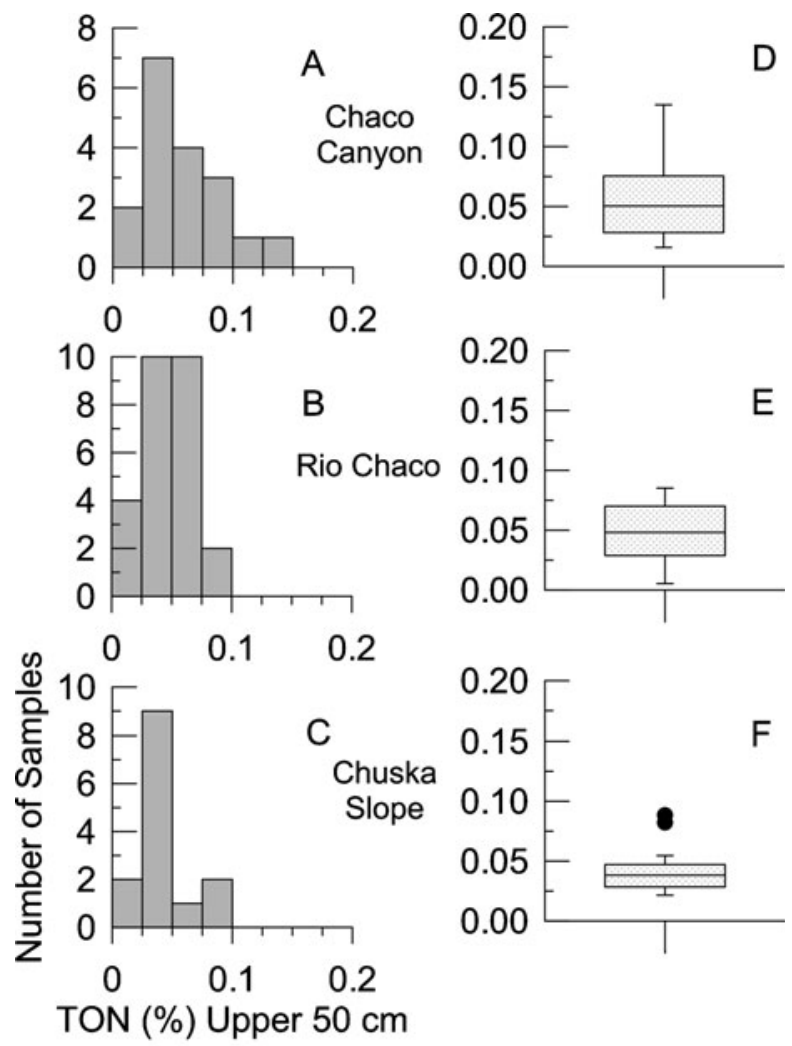

\begin{tabular}{|c|c|c|c|}
\hline & \multicolumn{3}{|c|}{ Chaco Halo } \\
\hline & Canyon & Rio Chaco & Chuska \\
\hline & \multicolumn{3}{|c|}{ TON (\%) Upper $50 \mathrm{~cm}$} \\
\hline Mean & 0.057 & 0.048 & 0.043 \\
\hline uartile & 0.028 & 0.029 & 0.028 \\
\hline d Quartile & 0.050 & 0.048 & 0.038 \\
\hline 3rd Quartile & 0.075 & 0.070 & 0.047 \\
\hline
\end{tabular}

Fig. 24 TON concentrations in the upper $50 \mathrm{~cm}$ of soil within the Chaco Canyon, Rio Chaco (upstream and downstream from Chaco Canyon), and Chuska Slope areas within the Chaco Halo

The calculations also assume that neither organic nitrogen nor $\mathrm{NO}_{3}-\mathrm{N}$ are supplied to the field over time from sources outside the field and that all $\mathrm{NO}_{3}-\mathrm{N}$ not consumed by the plants is lost from the system. A range of mineralization rates (1$3 \% /$ year) have been applied to the first, second, and third quartile values of measured organic $\mathrm{N}$ concentrations in the four archaeological regions as well as to Morfield Valley.

The results of the calculations indicate that fields in the Chaco Halo that can produce $10 \mathrm{bu} / \mathrm{ac}$ are limited to those fields with the highest organic $\mathrm{N}$ concentrations (third quartile) and the highest rate of mineralization (3\%) (Table 10). At Bandelier, production of $10 \mathrm{bu} / \mathrm{ac}$ is also associated with a mineralization rate of $3 \%$. Soils at Mesa Verde and Zuni are progressively more productive, and Morfield 

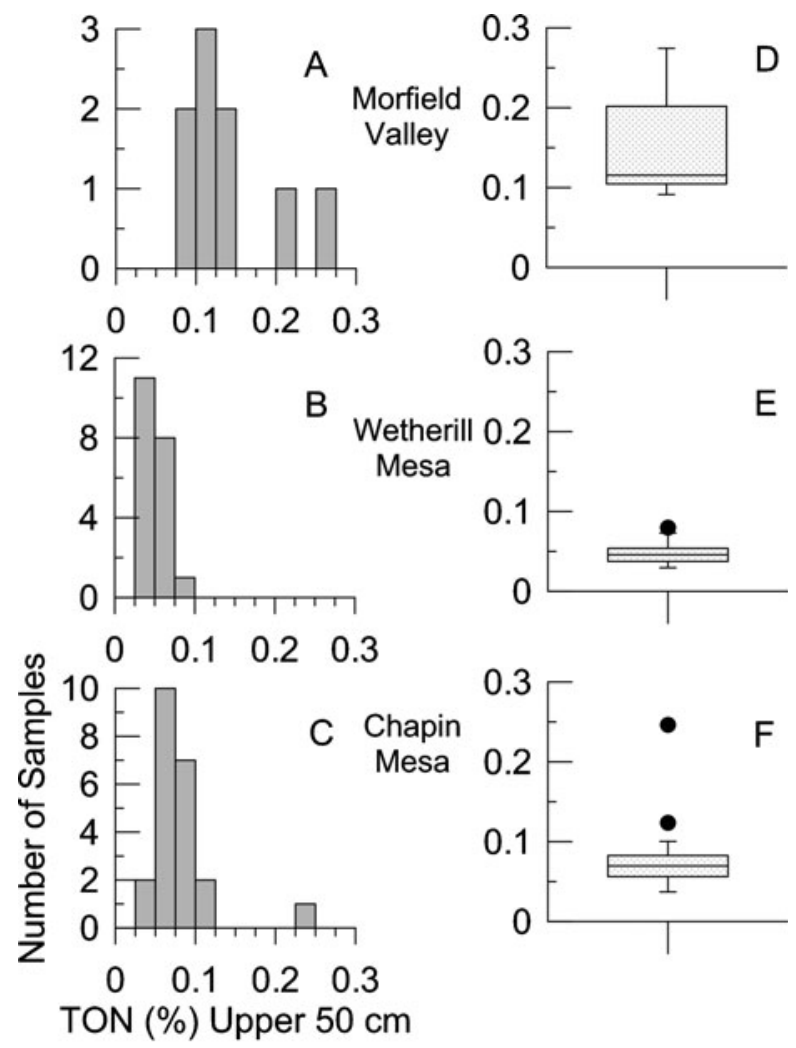

\begin{tabular}{|c|c|c|c|}
\hline & \multirow{2}{*}{$\begin{array}{c}\text { Morfield } \\
\text { Valley }\end{array}$} & \multicolumn{2}{|c|}{ Mesa Verde Top } \\
\hline & & Chapin & Wetherill \\
\hline & \multicolumn{3}{|c|}{ TON (\%) Upper $50 \mathrm{~cm}$} \\
\hline $\mathrm{Tu}$ & 0.140 & 0.079 & 0.047 \\
\hline & 0.101 & 0.056 & 0.037 \\
\hline & 0.116 & 0.070 & 0.046 \\
\hline ו & 0.169 & 0.083 & 0.054 \\
\hline
\end{tabular}

Fig. 25 TON concentrations in the upper $50 \mathrm{~cm}$ of soil within the Morfield Valley, Wetherill Mesa, and Chapin Mesa areas of the Mesa Verde archaeological region

Valley is highly productive with decadal-scale production of maize even in some situations when the mineralization rate is as low as $1 \%$ (Table 10).

To some extent, the agricultural productivity and field-life calculations should be considered only in an illustrative sense, given their assumptions; however, they demonstrate a ranking of the potential agricultural productivity of the four archaeological regions in terms of their organic $\mathrm{N}$ concentrations and they are useful in assessing the impact of drought on maize production within the Southwest. If, e.g., we assume that drought results in $\mathrm{N}$-mineralization rates of $\leq 1 \%$ (due to the effect of soil moisture on bacterial activity), then it becomes obvious that $10 \mathrm{bu} / \mathrm{ac}$ of maize cannot be produced within the four regions (excepting parts of Morfield Valley) during megadrought. It should be noted that 


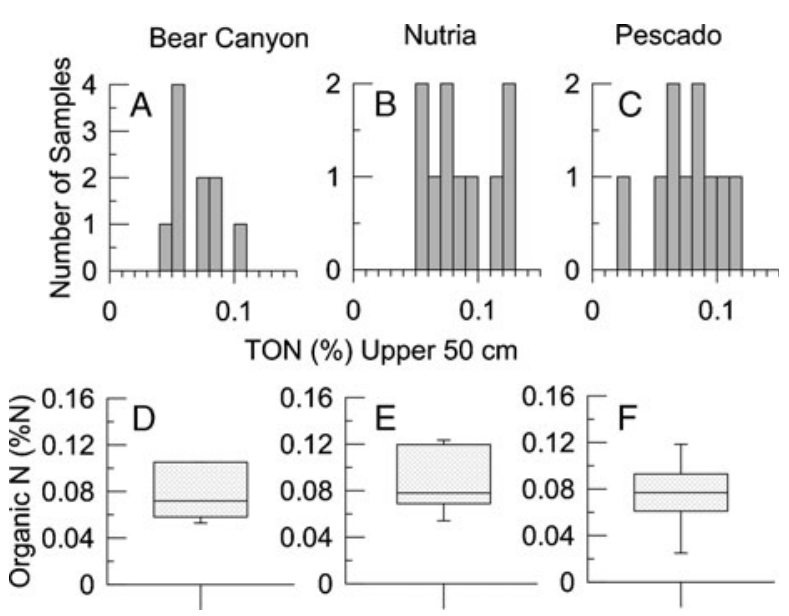

Fig. 26 TON concentrations in the upper $50 \mathrm{~cm}$ of soil within the three Zuni field systems

decreases in precipitation during megadrought may further impact agricultural productivity in the four regions.

\section{Comparison of Soil Chemical Data in This and Previous Studies}

Given that total $\mathrm{N}$ and TON values are essentially equivalent $\left(\mathrm{NO}_{3}-\mathrm{N}\right.$ and $\mathrm{NH}_{4}$ usually contribute little to the total $\mathrm{N}$ value), the $\mathrm{N}, \mathrm{pH}$, and TOC values in the top $50 \mathrm{~cm}$ of Zuni agricultural fields measured by Homburg (2000) and in this study are essentially the same (compare Fig. 8 with Figs. 18, 22, and 23). However, the $\mathrm{P}_{\mathrm{AV}}$ values measured by Homburg (2000) are slightly elevated with respect to $\mathrm{P}_{\mathrm{AV}}$ values measured in this study (Figs. 8 and 20).

If we compare the soil chemistry of the Dolores region (Fig. 9) to that of Mesa Verde (Table 8), we find that the $\mathrm{pH}$ of Dolores soils are slightly elevated compared to the $\mathrm{pH}$ of Mesa Verde soils, that $\mathrm{P}_{\mathrm{AV}}$ of Dolores soils are substantially elevated compared to the $\mathrm{P}_{\mathrm{AV}}$ of Mesa Verde soils, and that the EC of Mesa Verde soils are somewhat elevated compared to the EC of Dolores soils. No data on the organic $\mathrm{N}$ content of Dolores soils exist; however, if we apply the mean $\mathrm{C} / \mathrm{N}$ ratio of Mesa Verde soils (12.3 \pm 3.6 , Supplementary Table 2) to Dolores soils, the median organic $\mathrm{N}$ concentration in Mesa Verde soils $(0.060 \%)$ (Table 8) is substantially less than the calculated median organic $\mathrm{N}$ concentration in Dolores soils $(0.097 \%)$.

\section{Summary}

1. It is the thesis of this study that climate change in the form of extended anomalously wet and dry periods (megadroughts) forced prehistoric cultural response in the American Southwest and that the linkage between climate change and cultural response was mostly due to the dependence of a culture on maize production. 


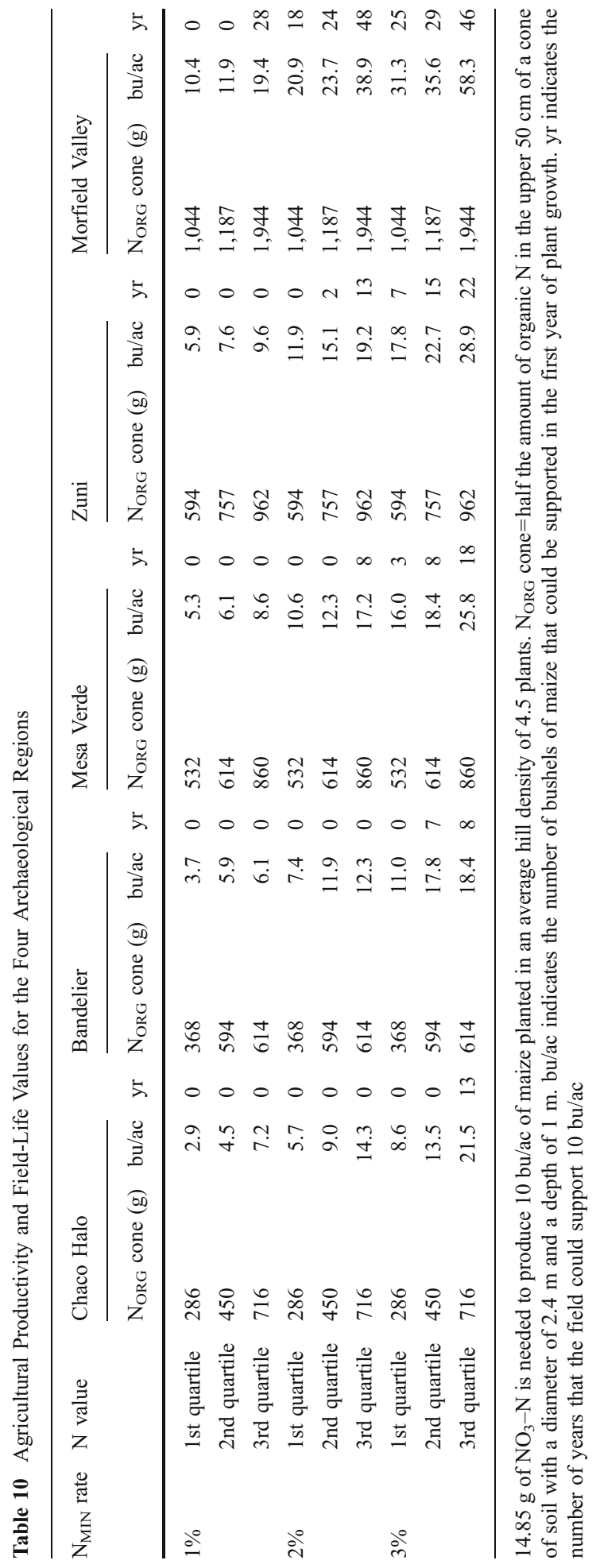


2. Both winter and summer precipitation are necessary for the production of maize. Mesa Verde precipitation is winter dominated, Los Alamos/Bandelier precipitation is summer dominated, and Chaco Canyon and Star Lake receive nearly equal amounts of winter and summer precipitation.

3. Summer rains contribute, on average, 10.5, 14.2, 15.2, and $25.7 \mathrm{~cm}$ of water, respectively, to Chaco Canyon, Zuni, Mesa Verde, and Los Alamos/Bandelier. These summer rains are temporally sporadic, comprising only a few intense convective events; e.g., a precipitation event in which $>0.99 \mathrm{~cm}$ of rain falls within a 24 -h period occurs only 0.65 times a month at Chaco, 1.3 times a month at Zuni, 1.1 times a month at Mesa Verde, and 2.1 times a month at Los Alamos/Bandelier.

4. During the 2 days it would take a silt loam to lose $1 \mathrm{~cm}$ of water to the atmosphere, a maize plant will only transpire between $1.2 \%$ and $5.8 \%$ of the $45,000 \mathrm{~cm}^{3}$ of water intercepted by the $4.5-\mathrm{m}^{2}$ root area.

5. Chaco Canyon, Zuni, Los Alamos, and Mesa Verde receive, on average, 7.2, $10.3,8.9$, and $21.3 \mathrm{~cm}$ of precipitable water that infiltrates the soil during the winter months.

6. In a silt loam soil, winter precipitation will, on average, penetrate to depths of approximately 24, 34, 30, and $71 \mathrm{~cm}$ at Chaco Canyon, Zuni, Los Alamos, and Mesa Verde.

7. Because summer rains contribute $50 \%$ or more of the total annual precipitation received by Zuni, Los Alamos, and Chaco, a dry water year is associated with a drier-than-average summer $>91 \%$ of the time and a wet water year is associated with a wetter-than-average summer $>77 \%$ of the time; i.e., the increase or decrease in summer moisture "levers" the annual value.

8. Summer precipitation at the four sites is not strongly linked, either in a positive or a negative sense, to the previous winter's precipitation, and the winterrelated tree-ring widths discussed in this paper are not useful in estimating summer precipitation.

9. Unlike the Midwest, the Southwest is relatively dry in the spring; therefore, the timing and amount of precipitation in the Southwest is not particularly conducive to the mineralization of soil organic matter and the production of $\mathrm{NO}_{3}-\mathrm{N}$ during the early growth stages of maize in spring and early summer. This implies that the carryover of stored winter soil moisture through the early part of the growing season is an important factor in the production of maize in the semi-arid Southwest.

10. Many and perhaps most Southwest Native American landraces require about 120 FFD and about 1,000 GDD. The great majority of the growing seasons at Zuni, Los Alamos, and Mesa Verde exceed 120 FFD; however, nearly half the growing seasons at Chaco and Star Lake do not meet this criterion. Most of the growing seasons at Zuni, Los Alamos, and Mesa Verde exceed 1,000 GDD; however, approximately one third of the growing seasons at Chaco and Star Lake do not meet this criterion.

11. Excessive heat (GDD) can cause increases in bare-soil evaporation to the point that the added heat may negatively impact soil moisture, causing the plant to wilt.

12. Historical climate data sets (GDD, FFD, summer moisture, annual moisture) for the past 60 years indicate that maize can be reliably grown at Los Alamos 
almost every year, that winter or summer precipitation is deficient at Zuni about $50 \%$ of the time, that summer precipitation limits Mesa Verde maize production about $60 \%$ of the time, and that at Chaco and Star Lake all four climate criteria are met only a few times.

13. Tree-ring widths in the four archaeological regions are mostly correlated with cool-season precipitation that begins in October of the previous year and ends in March of the ring year.

14. Floodplain soils along the Rio Chaco, including Chaco Canyon, are highly compacted and difficult to auger.

15. Loessic soils that cap Mesa Verde are highly permeable, well drained, and probably contain little or no expandable clay minerals which trap and hold moisture.

16. Soil salinity does not present a threat to the cultivation of maize at Mesa Verde, Zuni, or Bandelier; however, some of the soils within Chaco Canyon, along the Rio Chaco, and within the Chuska Slope possess elevated EC values. In particular, Chaco Canyon and Rio Chaco floodplain soils tend to have much higher salinities than Chaco Canyon side-tributary soils.

17. Soil $\mathrm{pH}$ at Mesa Verde and Bandelier is near optimal whereas Zuni values are slightly elevated; however, $\mathrm{pH}$ values in Chaco Halo soils are 2 units higher than at the other regions and are non-optimal with regard to the growing of maize.

18. Generally speaking, soils within the four archaeological regions have sufficient $\mathrm{P}_{\mathrm{AV}}$ values for the production of maize; however, $\mathrm{P}_{\mathrm{AV}}$ is less than optimal in about one quarter of the soils at Bandelier.

19. Bandelier and Mesa Verde plateau-top soils contain less than optimal $\mathrm{NO}_{3}-\mathrm{N}$ values as do half of all Zuni soils. The low $\mathrm{NO}_{3}-\mathrm{N}$ values may, in part, reflect the time of soil sampling; i.e., sampling in these areas occurred between the middle of July and the end of September, a period during which much of the $\mathrm{NO}_{3}-\mathrm{N}$ reservoir may have been depleted as a result of plant growth.

20. Many of the Chaco Halo soils contain elevated $\mathrm{NO}_{3}-\mathrm{N}$ values; however, at least $60 \%$ of the elevated values are associated with elevated ECs, which imply the presence of accumulated salts or saline soil waters within the soils.

21. The results of agricultural productivity and field-life calculations indicate that fields in the Chaco Halo that can produce $10 \mathrm{bu} / \mathrm{ac}$ are limited to those with the highest organic $\mathrm{N}$ concentrations (third quartile) and the highest rate of mineralization (3\%). At Bandelier, production of $10 \mathrm{bu} / \mathrm{ac}$ of maize is associated with a mineralization rate of $3 \%$. Soils at Mesa Verde and Zuni are progressively more productive, and Morfield Valley is highly productive with decadal-scale production of maize even in some situations when the mineralization rate is as low as $1 \%$.

22. If we assume that drought results in $\mathrm{N}$-mineralization rates of $\leq 1 \%$ (due to the effect of soil moisture on bacterial activity), then it becomes obvious that $10 \mathrm{bu} / \mathrm{ac}$ of maize cannot be produced within the four regions (excepting parts of Morfield Valley) during megadrought.

\section{Discussion and Conclusions}

In Part 1 of this study (Benson 2010), we learned that the San Juan Basin is unsuitable for optimal dryland cultivation of maize. It is deficient in both summer and annual 
precipitation, and many of the basin's soils are saline below a depth of $50 \mathrm{~cm}$. In addition, soils in the San Juan Basin contain low organic N concentrations and are characterized by elevated $\mathrm{pH}$ values $(>8)$ which, respectively, restrict field life and nutrient availability.

At the periphery of the basin, higher-elevation sites are associated with increased precipitation which promotes increased soil moisture and greater organic $\mathrm{N}$ concentrations. The increased soil moisture flux also removes soluble compounds from the soil column. Increasing elevation at the basin periphery also is associated with cooler temperatures, which decrease the rate of bare-soil evaporation but shorten the growing season. The enhanced moisture promotes the growth of plants that produce organic acids that promote slightly acidic soil waters, which enhance the solubility of organic $\mathrm{N}$ and $\mathrm{P}$.

This suggests that dryland farming within the overall study area will tend to be associated with an elevational band that changes its position each year in response to climate variability, a concept Petersen (1986) introduced and applied to southwestern Colorado.

The four archaeological regions, which are the subjects of this study, lie at different elevations. The Mesa Verde plateau slopes from about 2,440 $\mathrm{m}$ at its north edge to about 2,040 $\mathrm{m}$ at its south edge. The upper end of Morfield Valley is at an elevation of 2,365 m; it slopes to the south, reaching $1,855 \mathrm{~m}$ at its confluence with Prater Valley. The Bandelier soils transect ranges from $2,310 \mathrm{~m}$ at the northeast end of the Bandelier National Monument to $1,850 \mathrm{~m}$ at the visitor center. Most Zuni fields lie at elevations between 2,000 and 2,200 m. With regard to the Chaco Halo, the base of the Chuska Slope is at an elevation of about $1,700 \mathrm{~m}$, the elevation of Chaco Canyon is about $1,885 \mathrm{~m}$, and the extreme east end of the Halo lies at an elevation of about 1,960 m.

During drought, higher-elevation fields could have been developed within the Mesa Verde, Bandelier, and Zuni archaeological regions in order to intercept more moisture and to decrease bare-soil evaporation rates. However, this was not an option for much of the Chaco Halo, excepting the Chuska Slope, which ranges in elevation from 1,700 to about $1,900 \mathrm{~m}$.

Given available climate and soil-chemistry data, the four archaeological regions can be ranked in terms of their agricultural potential. With respect to precipitation and heat (GDD and FFD), the Los Alamos/Bandelier/Pajarito Plateau area has excellent agricultural potential, the agricultural potential of the Zuni and Mesa Verde areas is good, and the agricultural potential of the Chaco Halo is poor (Table 6). With respect to soil salinity, Bandelier, Zuni, and Mesa Verde EC values are near optimal; however, some soils within the Chaco Halo, especially floodplain sites, are non-optimal for the production of maize. With respect to $\mathrm{pH}$, Bandelier and Mesa Verde soils exhibit near-optimal values, Zuni $\mathrm{pH}$ values are slightly elevated, and Chaco Halo soils have elevated non-optimal $\mathrm{pH}$ values.

Calculations of $\mathrm{N}$ mineralization and field life (Table 10) indicate that Morfield Valley in Mesa Verde should be able to provide $10 \mathrm{bu} / \mathrm{ac}$ of maize for decades (without the addition of $\mathrm{N}$ ) if organic $\mathrm{N}$-mineralization rates exceed $2 \%$. Productivity and field-life potential decrease in the following order: Zuni, Mesa Verde, Bandelier, Chaco Halo; however, with the exception of Zuni, field longevities are short when the Nmineralization rate falls below 3\%/year. The Chaco Halo is very unproductive; e.g., $10 \mathrm{bu} / \mathrm{ac}$ can be achieved within the Halo only from soils having the highest organic $\mathrm{N}$ concentration (third quartile) and that undergo the highest rate $(3 \%)$ of $\mathrm{N}$ mineralization. 
The results of agricultural productivity and field-life calculations displayed in Table 10 can also be used to illustrate the effect of drought on $\mathrm{NO}_{3}-\mathrm{N}$ availability, given that the $\mathrm{N}$-mineralization rate is a function of soil moisture with higher moisture levels promoting more rapid mineralization. To illustrate the importance of climate change on maize production from a nutrient standpoint, it is assumed that, during anomalously dry periods, the $\mathrm{N}$-mineralization rate falls to $\leq 1 \%$ /year and that, during anomalously wet periods, the rate rises to $\geq 3 \%$ /year. From the data in Table 10 , it is evident that, during dry periods, not enough organic $\mathrm{N}$ is mineralized to produce $10 \mathrm{bu}$ of grain per acre in any of the four regions; however, during wet periods, sufficient organic $\mathrm{N}$ is mineralized to produce $10 \mathrm{bu}$ of grain per acre at Bandelier, Mesa Verde, and Zuni. During a wet period, even some of the Chaco Halo soils are productive.

The data discussed above indicate that dryland maize agriculture is a risky business in the American Southwest, even during periods of "normal" climate. During droughts, especially persistent megadroughts, there is insufficient precipitation to support transpiration that accompanies plant growth. Bare-soil evaporation rate increases, decreasing soil moisture, salts accumulate in the soil column, and the N-mineralization rate decreases.

To counter some of the risks associated with dryland agriculture, Southwestern Native Americans concentrated water and diverted it to agricultural fields. In some cases, they also chose field settings that were naturally fertilized with organic N; e.g., alluvial fan settings within side-valley tributaries allow for both these practices. Water, fine sediment, and organic matter can be trapped in the upper parts of gently sloping fans behind sediment berms that intersect runoff before it infiltrates the fan surface. These materials can also be concentrated and trapped at the distal ends of alluvial fans (ak-chin farming), although there is risk in that many runoff events may not reach the distal end of the fan. Creation of berms that intersected overland flow down side valleys tributary to the Rio Chaco would have allowed the concentration of water in this semi-arid landscape. Judd (1954) documented several instances of Navajo families who farmed side-valley tributary drainages in Chaco Canyon and the Kin Bineola Valley, using check dams and embankments.

Historically, the Zuni have practiced the ak-chin method of water and sediment concentration, placing their field systems on side-valley alluvial fans and mesa footslopes where storm waters from upland watersheds are diverted to fields and managed using earthen and wooden berms as well as shallow ditches. Zuni agricultural practices also entail the natural transport of organic $\mathrm{N}$ to their field systems which greatly prolongs field life. Nitrogen-fixing plants, in particular, antelope bitterbrush (Purshia tridentata), occur in some abundance in upland settings at Zuni and on the Mesa Verde plateau surface. No doubt some of the N-rich leaves lost annually by bitterbrush reach Zuni ak-chin fields during runoff events.

At Mesa Verde, bitterbrush would have increased the organic N content of plateau soils over time; however, elimination of bitterbrush and other shrubs during field creation would have eliminated the natural input of organic $\mathrm{N}$ to the field; i.e., the very shallow slope of the plateau does not permit the natural transport of organic material to the field and it also makes water concentration difficult. Bitterbrush appears along the edge of the north rim of Chaco Canyon; however, it does not appear to populate side canyon alluvial fans.

Many of the Bandelier soils are composed of highly permeable volcanic ash. The high permeability soils act as lithic mulch, encouraging the rapid infiltration of 
winter and summer moisture; however, the high permeability also makes water concentration difficult. Although bitterbrush does not occur at Bandelier, mountain mahogany (Cercocarpus), another $\mathrm{N}$ fixer, does populate the landscape.

Water concentration can occur during summer convective storms; however, water concentration of snowmelt is usually not feasible. This suggests that archaeological regions that receive little winter moisture, e.g., the Chaco Halo (Table 4), are particularly susceptible to winter drought; i.e., insufficient winter moisture will make the germination and sprouting of maize difficult. In addition, there also may be insufficient soil moisture for the plant to survive until the onset of summer convective events. The Mesa Verde region receives substantial winter precipitation (Table 4), which, to some extent, mitigates the problematic occurrence of sufficient summer moisture. Check dams were employed within the upper part of numerous side-valley drainages that descend from the Mesa Verde plateau (Nordenskiold 1893; Rohn 1963; Stewart and Donnelly 1943); however, their total acreage relative to the overall mesa top area is small.

One way to counter moisture and nutrient stress is to grow maize at a different plant density and hill spacing. Hill spacing can be reduced from 3.0 to $2.4 \mathrm{~m}$ before between-hill root systems begin to overlap and compete for water and nutrients. In addition, reducing plant density to two plants per hill decreases the moisture and nutrient demands by a factor of 2.25 . Therefore, a field containing 700 hills each having two plants should be capable of producing seven bushels per acre but would only require $6.6 \mathrm{~g}$ of $\mathrm{NO}_{3}-\mathrm{N}$ per root cone. Under these conditions, a mineralization rate of $\geq 2 \%$ /year would result in a 7-bu-per-acre crop for all Bandelier, Mesa Verde, and Zuni fields and for most Chaco Halo fields (Table 11). Even during a drought scenario, in which the $\mathrm{N}$-mineralization rate had fallen to $1 \%$ /year, some fields in Mesa Verde, Zuni, and the Chaco Halo sown at these lower plant densities could produce maize (Table 11).

The results of this study indicate there are several risk factors associated with dryland maize production within the study area. Chief among these factors is the highly variable convective activity (thunderstorms) associated with the summer monsoon. This leads to great spatial variability in the amount (if any) of summer precipitation received at any particular site (Adams and Comrie 1997). One way prehistoric Southwestern Native Americans may have responded to the spatial variability of summer precipitation was to spread over the landscape in such a way that at least some groups would receive adequate summer precipitation for the cultivation of maize during a "normal" year. In fact, one of the principal methods in locating Chacoan community centers in the San Juan Basin (Marshall et al. 1979) involved the location of small "green" areas in the Basin, using false-image Landsat photos (John Stein, personal communication 2009). The spatial distribution of great houses and their attendant villages prior to 1130 A.D. (see, e.g., figure 1.2 in Mahoney and Kantner 2000) supports the existence of such a strategy, and the great houses themselves may have served as intra- and inter-village maize redistribution centers based on kinship relations. Widespread megadrought associated with the failure of winter and (or) summer precipitation would, however, render dysfunctional such a system of maize redistribution.

This discussion should not be interpreted to indicate that the production of maize ceased altogether during megadrought or at any other time for that matter. In fact, 


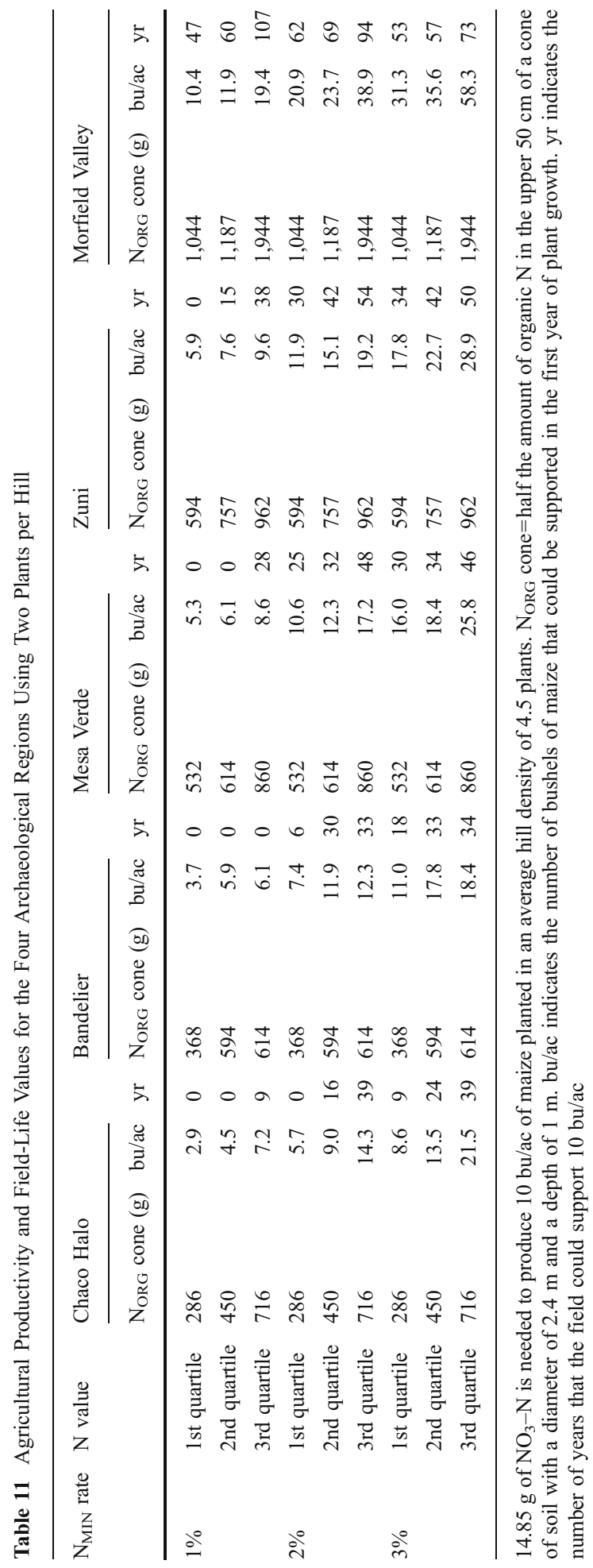


there always exist some environments that remain suitable for the production of maize under any climatic condition, e.g., along perennial river systems during drought. However, this study has demonstrated that maize production is a risk-prone activity throughout much of the study area at any particular time. Different parts of the study area are associated with different risk factors; e.g., maize production at Mesa Verde is highly dependent on summer precipitation, maize production within the Chaco Halo is sensitive to winter precipitation and $\mathrm{N}$ availability, and maize production at Bandelier is highly dependent on both $\mathrm{N}$ and $\mathrm{P}$ availability.

Water is the master variable that governs maize production. During photosynthesis, soil water is transpired to the atmosphere and soil moisture is a major control on both $\mathrm{N}$ mineralization rate and $\mathrm{P}$ availability. This suggests that, over time, the maize sustenance base fluctuated markedly in response to precipitation variability and implies that the overall study-area human population likely also oscillated in response to changes in precipitation.

Climate forcing of population dynamics via reduction in the maize subsistence base is amply illustrated by comparing the tree-ring-cutting-date distribution for the southern Colorado Plateau with a normalized tree-ring-based precipitation record for the southeastern Colorado Plateau (Fig. 27). Tree-ring dates are qualitative indicators of population change. Although it is impossible to equate the number of people

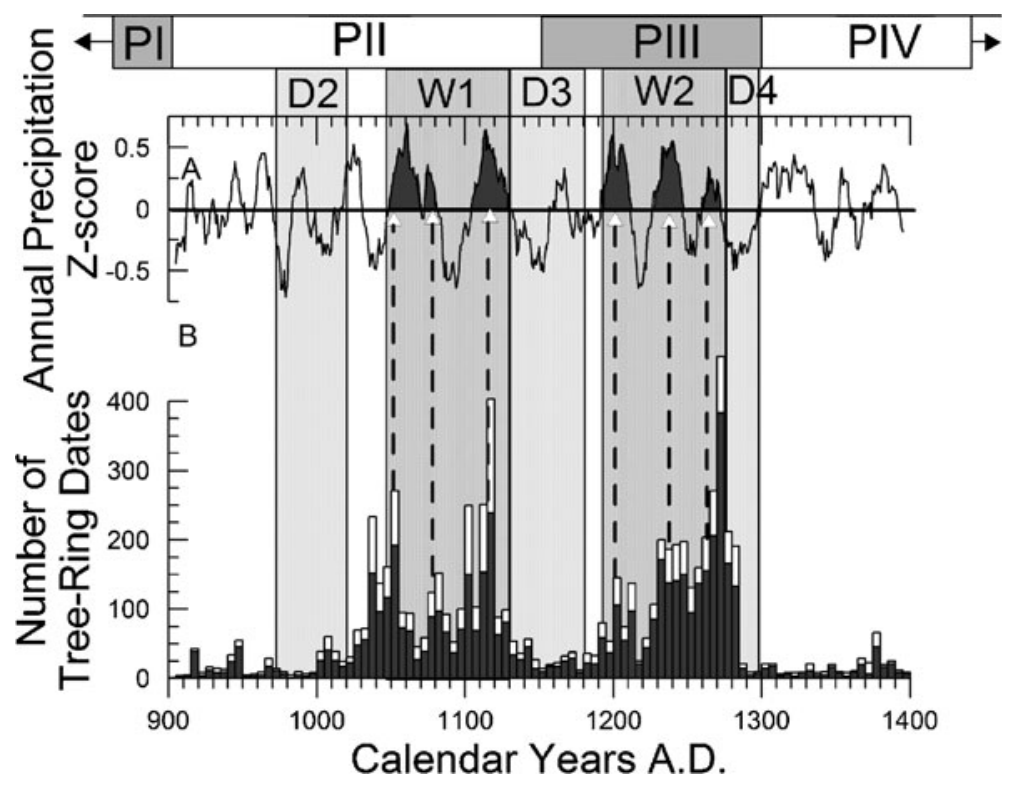

Fig. 27 Comparison of pan-regional tree cutting-date distribution with tree-ring-based precipitation records and archaeological stage boundaries. a Mean of six normalized tree-ring-based precipitation records from sites within and at the edge of the San Juan. b Distribution of tree-ring dates for the period 900-1400·A.D. (data from Benson and Berry 2009). Black values indicate "death" dates and white values indicate "v" dates (dates that are a few years older than the death date). Three megadroughts (D2-D4) have been colored light gray; two extended wet periods (W1-W2) have been colored dark gray. D3 is the mid-twelfth-century megadrought and D4 is the late-thirteenth-century megadrought. Dashed lines between cutting-date distribution and precipitation records between beginning of W1 and end of W2 indicate correlations of exceptionally wet times with intense tree harvesting and construction. $P$ indicates Pueblo cultural stages 
inhabiting a structure with the number of dendrochronologically dated timbers from that structure, maxima in regional-scale cutting distributions should indicate times of accelerated tree harvesting and construction. It is reasonable to assume that population increases accompanied increases in construction, although the relation between the two parameters cannot be quantitatively linked. The data displayed in Fig. 27 indicate that, in general, spikes in construction activity occurred during wet periods and that little or no construction occurred during the mid-twelfth- and late-13th-century megadroughts, supporting the concept that the Native American population responded to changes in precipitation via the latter's effect on the subsistence base.

\section{Future Research}

There are a number of ways that our understanding of the agricultural potential of Southwestern soils could be improved. First, actual dry weights of grain, stover, and the root mass and volume of a variety of Southwestern Native American maize landraces should be obtained. In addition, detailed studies of the fate of $\mathrm{N}$ and water within the soil column could be undertaken for dryland field systems, some of which employ water concentration. In particular, it would be important to determine how $\mathrm{NO}_{3}-\mathrm{N}$ is temporarily stored within and outside of the root zone. This would involve instrumentation of a number of archetypal field sites in order to monitor the flux of water and the production and flux of $\mathrm{NO}_{3}-\mathrm{N}$ over the annual cycle for several years characterized by differing rainfall and (or) water-concentration rates.

Acknowledgments The author wishes to thank Richard Friedman and Eleanor Griffin for producing the sampling area base maps. Olivia Woodruff and Randall Chiu performed many of the soil-chemistry analyses under the supervision of Terry Plowman. John Stein and Richard Loose participated in the sampling of the Bandelier area; Rory Gauthier guided the sampling at Bandelier. Kenneth Petersen assisted in the sampling of Mesa Verde. John Stein assisted in the sampling of the Chaco Halo, and Daniel Bowannie and Pete Peynetsa guided and assisted in the sampling of the three Zuni field systems. Richard Smith, Keith Lucey, Kenneth Petersen, and Jeffrey Homburg reviewed earlier versions of this manuscript. The author also wishes to thank the Chaco Culture National Historical Park, Mesa Verde National Park, Bandelier National Monument, and the Navajo Nation for access to their lands. Special thanks to George San Miguel and Scott Travis at Mesa Verde National Park, Rory Gauthier at Bandelier National Monument, Dabney Ford at Chaco Culture National Historical Park, Roman Pawluk at Zuni, and John Stein at the Navajo Nation for facilitating the sampling program. Dave Meko and Jeffrey Dean allowed the author access to some of the tree-ring data sets presented in this paper. My appreciation also to James Ashby who supplied most of the climate data used in this paper. Jeffrey Homburg who provided field maps which indicated the sites he sampled in Zuni and provided the author with EXCEL files of his soil-chemistry data sets. This study was supported by the National Science Foundation grant no. DEB-0816400 and the National Research Program of the U.S. Geological Survey.

\section{References}

Abdul-Jabbar, A. S., Sammin, J. W., Lugg, D. G., Kallsen, C. E., \& Smeal, D. (1983). Water use by alfalfa, maize, and barley as influenced by available soil water. Agricultural Water Management, 6, 351-363.

Adams, D. K., \& Comrie, A. C. (1997). The North American Monsoon. Bulletin of the American Meteorological Society, 78, 2197-2213.

Allen, R. G., Pruitt, W. O., Raes, D., Smith, M., \& Pereira, L. S. (2005). Estimating evaporation from bares soil and the crop coefficient for the initial period using common soils information. Journal of Irrigation and Drainage Engineering, 131, 14-23. 
Arrhenius, G., \& Bonatti, E. (1965). The Mesa Verde loess. In Contributions of the Wetherill Mesa archaeological project (pp. 92-100). Salt Lake City: The University of Utah Press. Memoirs of the Society of American Archaeology no. 18.

Barry, R. G. (1992). Mountain weather and climate. Cambridge: Cambridge University Press.

Bellorado, B.A. (2007). Breaking down the models: reconstructing prehistoric subsistence agriculture in the Durango District of Southwestern Colorado. Unpublished M.A. dissertation. Department of Anthropology, Northern Arizona University, Flagstaff

Benson, L.V. (2010). Factors controlling PreColumbian and early historic maize productivity in the American Southwest, Part 1: The southern Colorado Plateau and Rio Grande regions. Journal of Archaeological Method and Theory, XX, yy-pp.

Benson, L. V., \& Berry, M. S. (2009). Climate change and cultural response in the prehistoric American Southwest. Kiva, 75, 89-119.

Benson, L. V., \& White, J. W. C. (1994). Stable isotopes of oxygen and hydrogen in the Truckee RiverPyramid Lake surface-water system. 3. Sources of water vapor overlying Pyramid Lake. Limnology and Oceanography, 39, 1945-1958.

Berzsenyi, Z, \& Lap, D.Q. (2004). Studies on the effect of plant density on maize growth using the Richards Function. Proceedings of the 4th International Crop Science Congress, Brisbane, Australia.

Bradfield, M. (1971). The changing pattern of Hopi agriculture. Royal Anthropological Institute Occasional Paper No. 30.

Brown, G. M., Windes, T. C., \& McKenna, P. J. (2008). Animas anamnesis: Aztec ruins or Anasazi capital? In P. F. Reed (Ed.), Chaco's northern prodigies (pp. 231-250). Salt Lake City: The University of Utah Press.

Decker, K.W., \& Petersen, K.L. (1987). Sediment and chemical analyses of soil conservation service designated soils. In K.L. Petersen \& J.D. Orcutt (Compilers), Dolores archaeological program: supporting studies: settlement and environment (pp. 133-143). Denver: United States Department of the Interior, Bureau of Reclamation Engineering and Research Center.

Doolittle, W.E., \& Neely, J.A. (2004). The Safford Valley grids. Tucson: Anthropological Papers of the University of Arizona No. 70.

Fowler, A. P., \& Stein, J. R. (1992). The Anasazi great house in space, time, and paradigm. In D. E. Doyel (Ed.), Anasazi regional organization and the Chaco System (pp. 101-123). Albuquerque: Maxwell Museum of Anthropology. Anthropological Papers No. 5.

Friedman, R. A., Stein, J. R., \& Blackhorse, T., Jr. (2003). A study of a pre-Columbian irrigation system at Newcomb, New Mexico. Journal of GIS in Archaeology, 1, 4-10.

Gauthier, R., \& Herhahn, C. (2005). Why would anyone want to farm here? In R. P. Powers (Ed.), The peopling of Bandelier (pp. 27-34). Santa Fe: School of American Research Press.

Grissino-Mayer, H. D. (1996). A 2129-year reconstruction of precipitation for northwestern New Mexico, USA. In J. S. Dean, D. M. Meko, \& T. W. Swetnam (Eds.), Tree-rings, environment and humanity (pp. 191-204). Tucson: The University of Arizona Press.

Homburg, J.A. (2000). Anthropogenic Influences on American Indian Agricultural Soils of the Southwestern United States. Unpublished Ph.D. dissertation, Department of Agronomy, Iowa State University, Ames.

Homburg, J. A., Sandor, J. A., \& Norton, J. B. (2005). Anthropogenic influences on Zuni agricultural soils. Geoarchaeology, 20, 661-693

Jalota, S. K., \& Prihar, S. S. (1986). Effects of atmospheric evaporativity, soil type, and redistribution time on evaporation from bare soil. Australian Journal of Soil Research, 24, 357-366.

Judd, N. M. (1954). The material culture of Pueblo Bonito. Washington D.C.: The Smithsonian Institution.

Judge, W. J. (1989). Chaco Canyon-San Juan basin. In L. S. Cordell \& G. J. Gumerman (Eds.), Dynamics of Southwest prehistory (pp. 209-262). Washington D.C.: Smithsonian Institution Press.

Kintigh, K. W., Glowacki, D. M., \& Huntley, D. L. (2004). Long-term settlement history and the emergence of towns in the Zuni area. American Antiquity, 69, 432-456.

Latshaw, J. W., \& Miller, E. C. (1924). Elemental composition of the corn plant. Journal of Agricultural Research, 27, 845-861.

Lekson, S. H., \& Cameron, C. M. (1995). The abandonment of Chaco Canyon, the Mesa Verde migrations, and the reorganization of the Pueblo world. Journal of Anthropological Archaeology, 14, 184-202.

Lipe, W. D. (2010). Lost in transit: the central Mesa Verde archaeological complex. In T. A. Kohler, M. D. Varien, \& A. Wright (Eds.), Time of peril, time of change: explaining thirteenth-century Pueblo migration (pp. 270-297). Tucson: University of Arizona Press. 
Mahoney, N. M., \& Kantner, J. (2000). Chacoan archaeology and great house communities. In J. Kantner \& N. M. Mahoney (Eds.), Great house communities across the Chacoan landscape (pp. 1-15). Tucson: The University of Arizona Press.

Marshall, M. P., Stein, J. R., Loose, R. W., \& Novotny, J. E. (1979). Anasazi communities of the San Juan Basin. Albuquerque: Public Service Company of New Mexico, and Santa Fe: New Mexico Historic Preservation Bureau.

Meko, D. M., \& Baisan, C. H. (2001). Pilot study of latewood-width of conifers as an indicator of variability of summer rainfall in the North American Monsoon region. International Journal of Climatology, 21, 697-708.

Meko, D. M., Woodhouse, C. A., Baisan, C. A., Knight, T., Lukas, J. J., Hughes, M. K., \& Salzer, M. W. (2007). Medieval drought in the upper Colorado River Basin. Geophysical Research Letters, 34, L10705.

Muenchrath, D. A., Kuratomi, M., Sandor, J. A., \& Homburg, J. A. (2002). Observational study of maize production in semiarid New Mexico. Journal of Ethnobiology, 22, 1-33.

Nordenskiold, G. (1893). The cliff dwellers of Mesa Verde, southwestern Colorado. Glorieta, NM: Rio Grande Press, reprinted 1979.

Norton, E. R., \& Silvertooth, J. C. (1998). Field determination of permanent wilting point. In J. C. Silvertooth (Ed.), Cotton, a college of agriculture report series P-112 (pp. 230-237). Tucson: University of Arizona College of Agriculture and Life Sciences, Cooperative Extension Publication No. AZ1006.

Norton, J. B., Sandor, J. A., \& White, C. S. (2003). Hillslope soils and organic matter dynamics within a Native American agroecosystems on the Colorado Plateau. Soil Science Society of America Journal, 67, 225-234.

Norton, J. B., Sandor, J. A., \& White, C. S. (2007a). Runoff and sediments from Hillslope soils within a Native American agroecosystem. Soil Science Society of America Journal, 71, 476-483.

Norton, J. B., Sandor, J. A., White, C. S., \& Laahty, V. (2007b). Organic matter transformations through arroyos and alluvial fan soils within a Native American agroecosystem. Soil Science Society of America Journal, 71, 829-835.

Orcutt, J. D. (1991). Environmental variability and settlement changes on the Pajarito Plateau, New Mexico. American Antiquity, 56, 315-332.

Ortman, S. G. (2010). Evidence of a Mesa Verde homeland for the Tewa Pueblos. In T. A. Kohler, M. D. Varien, \& A. Wright (Eds.), Time of peril, time of change: explaining thirteenth-century Pueblo migration (pp. 233-269). Tucson: University of Arizona Press.

Petersen, K.L. (1986). Climate reconstruction for the Dolores Project area. In D.A. Breternitz, C.K. Robinson, \& G.T. Gross (Compilers), Dolores archaeological program: final synthetic report (pp. 311-331). Denver: United States Department of the Interior, Bureau of Reclamation Engineering and Research Center.

Petersen, K.L. (1987). Tree-ring transfer functions for estimating corn production. In K.L. Petersen \& J.D. Orcutt (Compilers), Dolores archaeological program: supporting studies: settlement and environment (pp. 217-231). Denver: United States Department of the Interior, Bureau of Reclamation Engineering and Research Center.

Richards, F. J. (1959). A flexible growth function for empirical use. Journal of Experimental Botany, 10 , 290-300.

Rohn, A. H. (1963). Prehistoric soil and water conservation on Chapin Mesa, southwestern Colorado. American Antiquity, 28, 441-455.

Rose, M.R., Dean, J.S., \& Robinson, W.J. (1981). The past climate of Arroyo Hondo, New Mexico, reconstructed from tree rings. Arroyo Hondo Archaeological Series 4. Santa Fe: School of American Research Press.

Sandor, J. A., Norton, J. B., Homburg, J. A., Muenchrath, D. A., White, C. S., Williams, S. E., et al. (2007). Biogeochemical studies of a Native American runoff agroecosystem. Geoarchaeology, 22, 359-386.

Singh, P., \& Singh, V. P. (2001). Snow and glacier hydrology. Dordrecht: Kluwer.

Stahle, D. W., Cook, E. R., Cleaveland, M. K., Therrell, M. D., Meko, D. M., Grissino-Mayer, H. D., et al. (2000). Tree-ring data document 16th century megadrought over North America. EOS Transactions of the American Geophysical Union, 81, 121-125.

Stewart, G.R. (1940). Conservation in Pueblo agriculture. Scientific Monthly, 56, 201-220, 329-340.

Stewart, G. R., \& Donnelly. (1943). Soil and water economy in the Pueblo Southwest: I. Field studies at Mesa Verde and northern Arizona. The Scientific Monthly, 56, 31-44.

Taiz, L., \& Zeiger, E. (2002). Plant physiology. Sunderland: Sinauer Associates.

USA Climate Archive, 2009. Online@ http://www.wrcc.dri.edu/summary/sodusa.html.

Varien, M. D., Lipe, W. D., Adler, M. A., Thompson, I. M., \& Bradley, B. A. (1996). Southwestern Colorado and Southeastern Utah settlement patterns: AD 1100-1300. In M. A. Adler (Ed.), The Prehistoric Pueblo world, AD 1150-1350 (pp. 86-113). Tucson: University of Arizona Press. 
Vivian, R. G. (1992). Chacoan water use and managerial decision making. In D. E. Doyel (Ed.), Anasazi regional organization and the Chaco system. Anthropological papers No. 5 (pp. 45-57). Albuquerque: Maxwell Museum of Anthropology, University of New Mexico.

Weaver, J. E. (1926). Root development of field crops. London: McGraw-Hill.

West, A. J. (1962). Snow evaporation from a forested watershed in the central Sierra Nevada. Journal of Forestry, 60, 481-484.

Western Regional Climate Center, 2009. Online@ @ttp://www.wrcc.dri.edu/.

Wilshusen, R. H., \& Van Dyke, R. M. (2006). Chaco's beginnings. In S. H. Lekson (Ed.), The archeology of Chaco Canyon: an eleventh century Pueblo Regional Center (pp. 211-259). Santa Fe: School of American Research Press.

Windes, T. C., \& Bacha, E. (2008). Sighting along the grain: differential wood use at the Salmon Ruin. In P. F. Reed (Ed.), Chaco’s northern prodigies (pp. 113-139). Salt Lake City: The University of Utah Press.

Wycoff, D. G. (1977). Secondary forest succession following abandonment of Mesa Verde. Kiva, 42, $215-232$. 